\title{
An Overview on Total Valorization of Litsea cubeba as a New Woody Oil Plant Resource toward a Zero-Waste Biorefinery
}

\author{
Yufei Qiu ${ }^{1}$, Yasi Yu ${ }^{1}$, Ping Lan ${ }^{2}$, Yong Wang ${ }^{1, *}$ and Ying $\mathrm{Li}^{1,3, * \mathbb{C}}$ \\ 1 Guangdong International Joint Research Center for Oilseeds Biorefinery, Nutrition and Safety, \\ Department of Food Science and Engineering, Jinan University, Guangzhou 510632, China; \\ qiuyufei224@stu2020.jnu.edu.cn (Y.Q.); yuyasi99@stu2017.jnu.edu.cn (Y.Y.) \\ 2 Faculty of Pharmacy, Institute for Advanced and Applied Chemical Synthesis, Jinan University, \\ Guangzhou 510632, China; ping.lan@jnu.edu.cn \\ 3 Qingyuan Yaokang Biotechnology, Qingyuan 513200, China \\ * Correspondence: twyong@jnu.edu.cn (Y.W.); yingli@jnu.edu.cn (Y.L.); \\ Tel.: +86-20-8522-0032 (Y.W. \& Y.L.); Fax: +86-20-8522-6630 (Y.W. \& Y.L.)
}

Citation: Qiu, Y.; Yu, Y.; Lan, P.; Wang, Y.; Li, Y. An Overview on Total Valorization of Litsea cubeba as a New Woody Oil Plant Resource toward a Zero-Waste Biorefinery. Molecules 2021, 26, 3948. https://doi.org/ $10.3390 /$ molecules 26133948

Academic Editor:

Teresa Escribano-Bailón

Received: 7 June 2021

Accepted: 24 June 2021

Published: 28 June 2021

Publisher's Note: MDPI stays neutral with regard to jurisdictional claims in published maps and institutional affiliations.

Copyright: (c) 2021 by the authors. Licensee MDPI, Basel, Switzerland. This article is an open access article distributed under the terms and conditions of the Creative Commons Attribution (CC BY) license (https:// creativecommons.org/licenses/by/ $4.0 /)$.

\begin{abstract}
With the increasing global demand for edible oils and the restriction of arable land minimum in China, woody oil plants have gradually become the optimal solution to cover the shortage of current edible oil supply and to further improve the self-sufficiency rate. However, due to the lack of knowledge and technique, problems like "how to make full use of these plant resources?" and "how to guide consumers with reasonable data?" limit the development of woody oilseed industry towards a sustainable circular economy. In this review, several emerging unique woody oil plants in China were introduced, among which Litsea cubeba as a new woody oil plant was highlighted as a reference case based on its current research progress. Unlike other woody oil plants, essential oil rather than oil from Litsea cubeba has always been the main product through the years due to its interesting biological activities. Most importantly, its major component, citral, could be the base for other synthesized perfume compounds with added value. Moreover, the sustainable biorefinery of large amounts of waste residual after Litsea cubeba essential oil processing is now technically feasible, which could inspire a total valorization pathway for other woody oil plants to make more competitive plant-based products with both economic, social, and ecological benefits.
\end{abstract}

Keywords: woody oil plant resource; Litsea cubeba valorization; essential oil bioactivities; citral-based value-added products; kernel oil and protein; zero-waste sustainable biorefinery

\section{Introduction}

Woody oil plant is the general term for the fruits or seeds of woody plants that can be used for oil extraction. It is a renewable resource for a diversity of oil products, such as edible oils, aromatic oils, industrial oils, and even oils for bioenergy [1]. The exploitation of woody oil plant based on the biorefinery concept is superior to conventional agriculture and more adaptable to climate change, which has advantages of using marginal land resources to develop value-added products and alleviating economic growth from dependence on fossil energy to some extent. Moreover, the industrial development of woody oil plants is also conducive to reduce the tight supply of edible oil, and meanwhile, maintain both economic stability and ecological security.

It is stated by the General Office of the State Council of China that 800 key counties would plant woody oilseeds like camellia, walnut, and peony by 2020, and a batch of standardized and industrialized demonstration bases would be established, resulting in the growing planting area from the existing 8 million hectares to around 13 million hectares, with an annual output of about 1.5 million tons of woody edible oils. Although woody oil plants in China are diverse and abundant, they are still unexploited or underdeveloped due to lack of scientific knowledge and systematic technical studies on intensive processing and integrated utilization. 
The depletion of fossil energy and the unprecedented global climate change force people to eagerly seek raw materials for the available biomass, responding to the demand of sustainable energy supply [2,3]. In recent years, with the rapid development of society and the increasing demand for a better life, some local woody oil plants in China like Camellia oleifera have gradually attracted more and more attention in both domestic and foreign markets due to their unique chemical compositions and functional properties [4]. Besides this, Litsea cubeba was found as an emerging woody oil plant resource that can be implemented in a total valorization toward a zero-waste biorefinery, resulting in various plant-based products with added value for different application fields.

\section{Woody Oil Plant Resources in China}

As a big agricultural country with vast territory and excellent natural conditions, China has a wide variety of indigenous woody oil plants such as Camellia oleifera, Juglans regia, Paeonia suffruticosa, Xanthoceras sorbifolium, Acer truncatum, Eucommia ulmoides, and Swida wilsoniana, whose morphological properties, seed oil content, and characteristic bioactive ingredients are shown in Table 1.

Table 1. Overview of six unique oil crops in China.

\begin{tabular}{|c|c|c|c|c|c|c|}
\hline \multirow[b]{2}{*}{ Woody Oil Plants } & \multirow[b]{2}{*}{ Family } & \multicolumn{4}{|c|}{ Chemical Composition of Seed Oil } & \multirow[b]{2}{*}{ References } \\
\hline & & $\begin{array}{c}\text { Seed Oil } \\
\text { Content }(\%)\end{array}$ & $\begin{array}{c}\text { Total } \\
\text { Unsaturated } \\
\text { Fatty Acids (\%) }\end{array}$ & $\begin{array}{c}\text { Unique } \\
\text { Bioactive } \\
\text { Substances }\end{array}$ & $\begin{array}{l}\text { Other Bioactive } \\
\text { Substances }\end{array}$ & \\
\hline Camellia oleifera & Theaceae & $1-58$ & $85-93$ & Camellin & $\begin{array}{l}\text { Squalene, tea saponin, } \\
\text { lignans, etc. }\end{array}$ & {$[5,6]$} \\
\hline Juglans regia & Juglandaceae & $59-68$ & $90-91$ & Juglone & $\begin{array}{l}\text { Minerals, melatonin, } \\
\text { phospholipid, } \\
\text { carotene, vitamin, etc. }\end{array}$ & {$[7,8]$} \\
\hline $\begin{array}{c}\text { Paeonia } \\
\text { suffruticosa }\end{array}$ & Paeonia & $28-31$ & $88-93$ & $\begin{array}{c}\text { Paeonol, } \\
\text { paeonoside }\end{array}$ & $\begin{array}{l}\text { Monoterpenes, } \\
\text { triterpenes, etc. }\end{array}$ & {$[9-11]$} \\
\hline $\begin{array}{l}\text { Xanthoceras } \\
\text { sorbifolium }\end{array}$ & Sapindaceae & $55-70$ & $83-88$ & $\begin{array}{l}\text { Nervonic acid, } \\
\text { saponin }\end{array}$ & $\begin{array}{c}\text { Sterols, } \\
\text { phospholipids, etc. }\end{array}$ & {$[12,13]$} \\
\hline Acer truncatum & Aceraceae & $38-55$ & $90-92$ & Nervonic acid & $\begin{array}{l}\text { Vitamin E, flavonoids, } \\
\text { coumarin, etc. }\end{array}$ & {$[14,15]$} \\
\hline $\begin{array}{l}\text { Eucommia } \\
\text { ulmoides }\end{array}$ & Eucommia & $32-37$ & $90-91$ & $\begin{array}{l}\text { Aucubin, } \\
\text { chlorogenic acid }\end{array}$ & $\begin{array}{c}\text { Iridoids, } \\
\text { phenylpropanoids, } \\
\text { lignans, etc. }\end{array}$ & {$[16,17]$} \\
\hline Swida wilsoniana & Cornaceae & $55-62$ & $74-82$ & Octacosanol & $\begin{array}{l}\beta \text {-sitosterol, } \\
\text { vitamin, etc. }\end{array}$ & [18-20] \\
\hline
\end{tabular}

\subsection{Camellia oleifera}

Camellia oleifera is one of four major woody oil plants in the world, and its seed oil enjoys the reputation of "Oriental olive oil" because of its similar fatty acid composition to that of olive oil in Europe. Camellia oil is rich in various bioactive ingredients, and long-term intake of camellia oil can regulate immune function; decrease cholesterol levels; lower blood sugar and lipids; and prevent hypertension, hepatic, cardiovascular, and neurological diseases [21-23]. Moreover, it has strong antioxidant activity and high thermal stability after refining; its good affinity to human skin can help to improve skin conditions and even reduce skin aging [24-26]. Therefore, it can be used as a cosmetic oil to make natural skin care products. In addition, camellia shell contains a large amount of cellulose, lignin, and hemicellulose, which can be used to produce industrial raw materials such as furfural, xylitol, tannin, and even biochar that can effectively remove fluoride in water [27]. 


\subsection{Juglans regia}

Juglans regia is one of the important nuts and woody oil species in China, where the planting area and total output of walnut rank first in the world. The oil content of walnut is almost the highest among all woody oils, which is known as "oil depot on the tree". Since walnut oil is rich in a variety of biologically active substances, they have important nutritional and health care values such as the function of strengthening brain and body, moistening lungs, and even beautifying skin. Besides, the integrated utilization of by-products from walnut oil processing has gradually become a hotspot, which greatly improves the economic benefits of walnuts. For instance, walnut pomace, husk, and oil cakes can be further processed to produce soy sauce, activated carbon, milk, pigment, polysaccharides, polyphenols, protein powder, and peptides [28-32].

\subsection{Paeonia suffruticosa}

Paeonia suffruticosa is an emerging woody oil plant with its unique flowers signifying "Celestial Beauty, the king of flowers", which is native to the basin of Yangtze River and Yellow River in China. The oil content and quality in peony seed is high, it has a comparable content of $\alpha$-linolenic acid to that in flaxseed oil, which has been reported to have the effect of lowering blood fat and improving cardiovascular disease and brain nerve function, as well as being anti-cancer and anti-inflammatory [33-35]. Furthermore, there are also many concomitant minor nutrients in peony seed oil, which have broad application prospects in the fields of medicine, cosmetics, and functional food.

\subsection{Xanthoceras sorbifolium}

Xanthoceras sorbifolium is a rare edible oil tree species, which is native to the Loess Plateau in northern China. It has now become the first selection species in desertification control and environmental protection. Xanthoceras sorbifolium seed oil is not only suitable to edible uses, but also can be applied in bioenergy field due to its similar chemical composition to that of ideal diesel substitutes. The quality indicators of biodiesel prepared from Xanthoceras sorbifolium oil as the feedstock met the condition and relevant regulations of fuel substitutes [36,37]. In addition, Xanthoceras sorbifolium oil also contains a variety of mineral elements and active ingredients, which has the potential to be applied in the field of medical care, functional food, and cosmetics.

\subsection{Acer truncatum}

Acer truncatum is another unique tree species in China, which was named after its samara shaping, like gold ingot from ancient China. Its seed oil was also approved as a new edible oil resource by the National Health Commission in China. Unlike other oils, Acer truncatum seed oil has a high content of unsaturated fatty acid ( $\geq 90 \%)$, essential fatty acids $(>50 \%)$, and multivitamins (e.g., vitamin E content is the highest among all plant oils), which brings itself great development prospects and economic benefits. The plant containing nervonic acid is scarce worldwide, thus Acer truncatum seed oil containing around 5.5\% of nervonic acid can be refined purposively and applied in medical drugs, health foods, and other fields, especially for the prevention and treatment of major neurological diseases such as Alzheimer's disease and Parkinson's disease [38,39].

\subsection{Eucommia ulmoide}

Eucommia ulmoides is a unique and precious woody oil plant in China, and its leaves, flowers, and fruits have medicinal and edible values. Hence, it is known as "Plants gold". Eucommia ulmoides seed oil is a kind of high-grade plant oil, which has remarkable pharmacological functions such as reducing blood fat and improving cardiovascular disease. It is interesting that Eucommia ulmoides gum extracted from its leaves has the durability of rubber and plastic, though it has no genetic relationship with rubber tree, which can be processed into polymer materials with different properties [40]. Such gum can also partially 
replace natural rubber and blend with other synthetic rubbers or plastics, which can expand its application in transportation, communication, and construction fields [41-43].

\subsection{Swida wilsoniana}

Swida wilsoniana is cultivated in China as an important woody oil plant with wide ecological adaptability. Both its pulp and kernels contain lots of oil with high value in both food and non-food field [18,44], in which the main fatty acid compositions are linoleic acid and oleic acid. Swida wilsoniana oil was approved as a new resource for food in 2013. Its oil is rich in unsaturated fatty acids, vitamin E, $\beta$-carotene, and other functional ingredients, which not only have hypolipidemic function, but also help to supply essential fatty acids and prevent fatty liver and atherosclerosis $[45,46]$. In addition, studies have shown that the Swida wilsoniana oil could be catalyzed to produce high-quality biofuels, which can be used as an alternative energy source with less competition with foods $[47,48]$.

\subsection{Litsea cubeba}

Litsea cubeba is a special woody oil plant resource in China, which is mainly distributed in provinces and regions in the south of the Yangtze River. For the past several decades, Litsea cubeba essential oil has been the only product for trading, which can be extracted from its whole plant, including leaves, flowers, fruits, trunks, and even roots. However, the limited essential oil yield $(\approx 4 \%)$ results in a large amount of kernel and pomace as wastes, which are underutilized and usually discarded to cause environmental burden. China is the largest producer and exporter o Litsea cubeba essential oil in the world. Most European countries import essential oils for further purification to obtain high-value functional products, and Litsea cubeba essential oil is no exception. Its main component citral has been used for the synthesis of high-grade fragrances (e.g., ionone, geraniol, citronellol and irone), and vitamin $\mathrm{A}$ and $\mathrm{E}$ as well. Apart from this, very few value-added processing studies have been reported for other residues after Litsea cubeba essential oil distillation. Considering this, this review proposes a total valorization pathway of Litsea cubeba toward a zero-waste biorefinery based on its current development status (Figure 1), which helps to make full use of this new woody oil plant resource to have various bio-based products with greater value (e.g., essential oil, citral-based derivatives, kernel oil, fatty acid, biofuel, surfactants, fodder, etc.) in different fields. The integrated utilization of Litsea cubeba may inspire a sustainable biorefinery route to produce plant-based products from other woody oil plant resources, resulting in the optimal compromise solution between economy, society, and environment. 


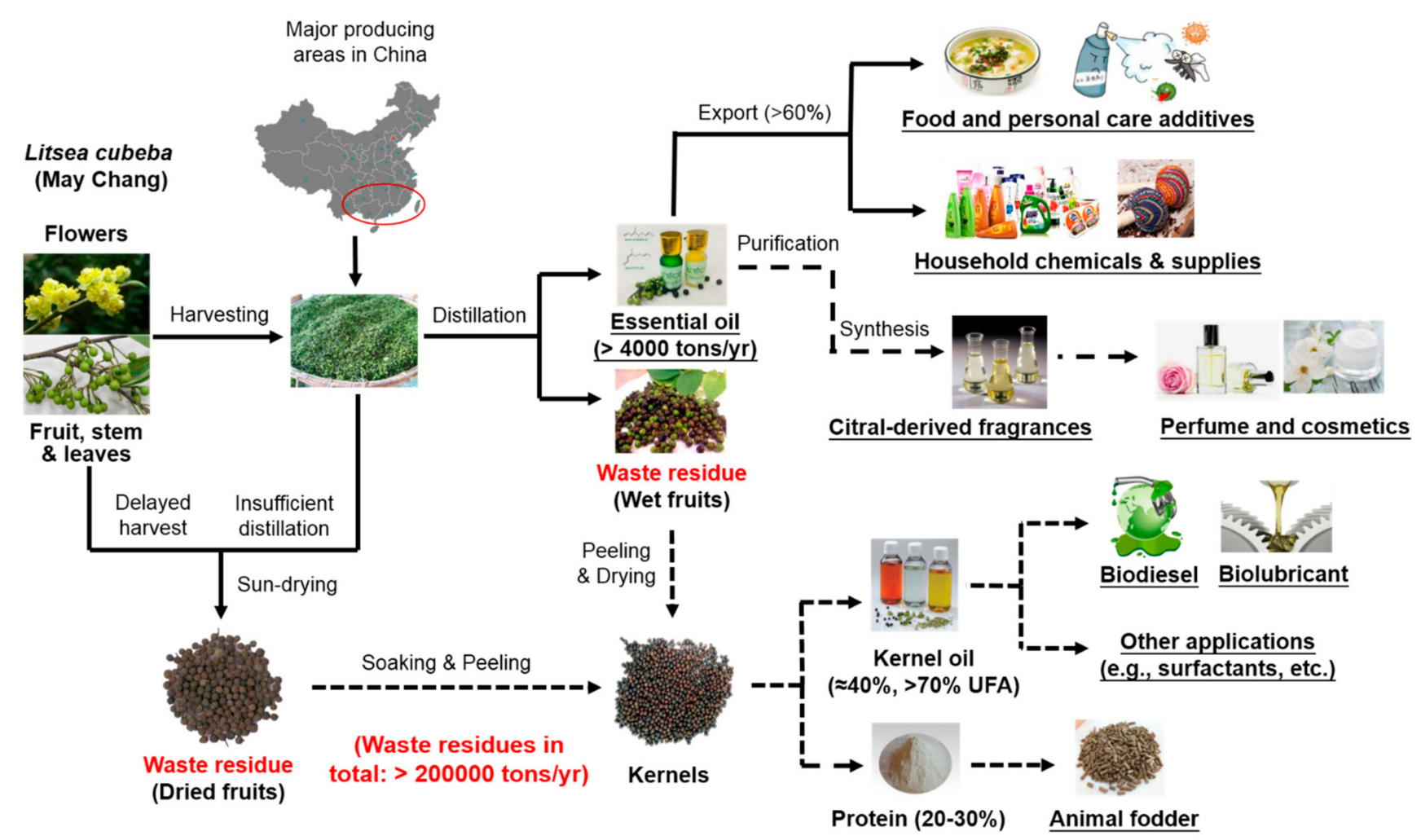

Figure 1. Sustainable biorefinery to produce plant-based products from Litsea cubeba (solid line: high technical maturity, half dashed line: medium technical maturity, full dashed line: low technical maturity).

\section{Litsea cubeba Essential Oil and Citral-Based Derivatives}

Litsea cubeba is a deciduous shrub or a small tree belonging to the Lauraceae family, which is a characteristic potential industrial crop in China. This plant is photophilous and shade tolerant, the good germination of its seed can make it easy to survive in the undergrowth or at the roadside. The yield and composition of essential oils vary depending on plant organs extracted (i.e., fruits, leaves, flowers, roots, and trunk), environmental conditions (e.g., soil, altitude, climate and irrigation), and other parameters (e.g., harvest time, ripeness and postharvest technologies). The main chemical constituents of Litsea cubeba essential oil are terpenoids, especially for citral, whose biological activities including antioxidant, anti-inflammatory, antimicrobial, and anthelmintic capacities, have attracted more interests in recent years. Furthermore, high value-added synthetic products derived from citral have also been favored by enterprises in the field of perfume, flavor and fragrance, and nutraceuticals.

\subsection{Extraction of Litsea cubeba Essential Oils}

It is reported that the yield of essential oil from Litsea cubeba fruits is higher than that from other plant organs [49]. The traditional methods for extracting essential oil from Litsea cubeba is hydrodistillation, which is simple to operate but usually with a low extraction rate. Moreover, the long treatment time may cause unexpected changes in chemical composition and smell. Hence, innovative extraction technologies (e.g., microwave-assisted extraction, ultrasonic-assisted extraction, enzymatic-assisted extraction, supercritical fluid extraction, and other combined extractions) have been developed for essential oils in the past decade [50-54], which can not only enhance the extraction efficiency in a shorter time, but also maintain or improve the quality of essential oils.

As summarized in Table 2, emerging techniques like microwave and ultrasound could effectively enhance the extraction of Litsea cubeba essential oils with good quality, which paved the way for the total valorization of this plant. The strong penetrating power of 
electromagnetic microwaves could accelerate diffusion and transfer of essential oils from interior gland cells of fruit and peel tissues to exterior. Compared to traditional steam distillation, the optimized microwave-assisted extraction (MAE) could increase the yield by 36.5-37.5\% but shorten the treatment time by four times [55]. Moreover, the citral content in essential oils was $5 \%$ higher and the amount of its loss in purification reduced by $33.3 \%$. MAE was also optimized with an average essential oil yield of up to $10.29 \%(\mathrm{~g} / \mathrm{g})$, which could improve to $14.19 \%$ (g/g) with the combination of ultrasound [56].

Table 2. Methods for extracting Litsea cubeba essential oils.

\begin{tabular}{|c|c|c|c|}
\hline Methods & Conditions & Experimental Remarks & References \\
\hline \multirow[t]{2}{*}{ Microwave-assisted extraction } & $\begin{array}{l}\text { Microwave irradiation time: } 10-20 \mathrm{~min} \\
\text { Microwave temperature: } 60-80^{\circ} \mathrm{C} \text {; } \\
\text { Distillation temperature: } 80-100^{\circ} \mathrm{C} \text {; } \\
\text { Distillation time: } 90-120 \mathrm{~min} .\end{array}$ & $\begin{array}{l}\text { Compared to conventional steam } \\
\text { distillation, the yield of essential oil } \\
\text { increased by } 36.5-37.5 \% \text { and the treatment } \\
\text { time was four times shorter. The citral } \\
\text { content was 5\% higher and the amount of } \\
\text { its loss in purification reduced by } 33.3 \%\end{array}$ & {$[55]$} \\
\hline & $\begin{array}{l}\text { Microwave power: } 650 \mathrm{~W} ; \\
\text { Extraction time: } 40 \mathrm{~min} ; \\
\text { Solid-liquid ratio: } 1: 4(\mathrm{~g} / \mathrm{mL})\end{array}$ & $\begin{array}{l}\text { Average yield of essential oil was up to } \\
\qquad 10.29 \%(\mathrm{~g} / \mathrm{g})\end{array}$ & {$[56]$} \\
\hline \multirow[b]{2}{*}{ Ultrasonic-assisted extraction } & $\begin{array}{l}\text { Liquid to solid ratio: } 3.2: 1 ; \\
\text { Vacuum distillation temperature: } 76^{\circ} \mathrm{C} \text {; } \\
\text { Particle size: } 80 \text { mesh; } \\
\text { Ultrasonic time: } 35 \text { min. }\end{array}$ & $\begin{array}{l}\text { The extraction rate under vacuum was } \\
6.94 \% \text {, which was } 33.98 \% \text { higher than the } \\
\text { that of conventional steam distillation. } \\
\text { The content of citral was } 87.65 \% \text {. }\end{array}$ & {$[57]$} \\
\hline & $\begin{array}{l}\text { Liquid to solid ratio: } 5: 1 ; \\
\text { Ultrasonic time: } 25 \mathrm{~min} ; \\
\text { Ultrasonic temperature: } 100^{\circ} \mathrm{C} \text {. }\end{array}$ & $\begin{array}{l}\text { Compared to hydrodistillation and steam } \\
\text { distillation, essential oil yield increased } \\
\text { with the ultrasonic time; the optimal } \\
\text { ultrasonic-assisted extraction was helpful } \\
\text { for obtaining high-purity citral. }\end{array}$ & {$[58]$} \\
\hline Enzymatic-assisted extraction & $\begin{array}{l}\text { Heterologous expressed expansin: } 500 \mathrm{~mL} \text {; } \\
\text { Cellulase: } 2.5 \mathrm{~g} ; \\
\text { Enzymolysis time: } 24 \mathrm{~h} ; \\
\text { Temperature: } 42{ }^{\circ} \mathrm{C} ; \\
\text { Centrifuge speed: } 3000 \mathrm{r} / \mathrm{min} .\end{array}$ & $\begin{array}{l}\text { Enzymatic-assisted extraction could } \\
\text { significantly improve the yield of essential } \\
\text { oil compared to conventional extraction. } \\
\text { The highest yield was obtained using } \\
\text { composite enzyme (cellulase and } \\
\text { expansin), which was } 1 / 3 \text { higher than that } \\
\text { using cellulose alone. }\end{array}$ & {$[59]$} \\
\hline Supercritical $\mathrm{CO}_{2}$ extraction & $\begin{array}{l}\text { Particle size: } 60-80 \text { mesh; } \\
\text { Extraction pressure: } 25 \mathrm{MPa} \text {; } \\
\text { Extraction temperature: } 45^{\circ} \mathrm{C} \text {; } \\
\text { Extraction time: } 60 \mathrm{~min} \text {; } \\
\mathrm{CO}_{2} \text { flow rate: } 1.5 \mathrm{~mL} / \mathrm{min} \text {. }\end{array}$ & $\begin{array}{l}\text { The extraction rate was up to above } 30.19 \% \\
\text { and the essential oil had clear color. }\end{array}$ & {$[60]$} \\
\hline \multirow[b]{2}{*}{ Combined extraction } & $\begin{array}{l}\text { Microwave power: } 600 \mathrm{~W} ; \\
\text { Extraction time: } 8 \mathrm{~min} ; \\
\text { Solid-liquid ratio: } 1: 7(\mathrm{~g} / \mathrm{mL}) \\
\text { Extraction temperature: } 85^{\circ} \mathrm{C} \text {. }\end{array}$ & $\begin{array}{c}\text { Average yield of essential oil of combined } \\
\text { extraction assisted by microwave and } \\
\text { ultrasound was up to } 14.19 \%(\mathrm{~g} / \mathrm{g}) \text {, which } \\
\text { was } 3.9 \% \text { higher than that extracted by } \\
\text { microwave solely. }\end{array}$ & {$[56]$} \\
\hline & $\begin{array}{l}\text { Oxalic acid/choline chloride: } 1: 1 ; \\
\text { Water content: } 50 \% \text {; } \\
\text { Liquid-solid ratio: } 12: 5: 1 \mathrm{~mL} / \mathrm{g} \\
\text { Homogenate time: } 2 \mathrm{~min} \\
\text { Microwave power: } 700 \mathrm{~W}\end{array}$ & $\begin{array}{l}\text { Deep eutectic solvent-homogenate based } \\
\text { microwave-assisted hydrodistillation was } \\
\text { developed to have a quite different major } \\
\text { compounds (e.g., m-cymeme, } \\
\text { trans-linalool, etc.) under optimal } \\
\text { conditions, which showed higher in vitro } \\
\text { radical scavenging activity but lower } \\
\text { antifungal activity. }\end{array}$ & {$[61]$} \\
\hline
\end{tabular}

Ultrasonic cavitation can speed up the breakage of plant cell walls, which is conducive to the release of essential oils and the penetration of solvents. Ultrasonic-assisted vacuum extraction was reported to have an extraction rate of $6.94 \%$ under optimal conditions, which had a citral content of as high as $87.65 \%$ [57]. Peng et al. [58] found that the yield of essential oils could be enhanced with the assistance of ultrasound, where the yield reached the highest when ultrasonic time was $25 \mathrm{~min}$. Although crushing could increase 
the extraction ratio, the purity of essential oils was lower, which was not recommended to the extraction.

It is well known that enzymes are highly specific and have high catalytic efficiency with mild reaction conditions. Generally, the use of appropriate enzymes can improve the extraction rate without any damages to the raw materials, which is beneficial to the further exploitation of the residues after extraction. The yield of essential oil varies widely depending on relevant factors such as enzyme types and dosages. Xie et al. [59] used recombinant expansin and cellulase to extract the Litsea cubeba essential oil, which significantly increased the yield of essential oil compared to conventional extraction. The function of expansin is to break the hydrogen bond between cellulose microfilaments and hemicellulose. The interaction of expansin and hydrolase facilitates expansion and disruption of plant cell wall without any losses of nutrients. Therefore, expansin, as a product of genetic engineering, is worthy to be further explored regarding the high price and large amount of enzyme used in the large-scale extraction.

The type of solvent is of great importance to extraction. Supercritical $\mathrm{CO}_{2}$ is one recognized green solvent for the extraction of bioactive components from natural plants, considering its excellent extractive properties, safety, eco-friendliness, and economica viability [62]. Supercritical $\mathrm{CO}_{2}$ extraction could not only avoid oxidation, degradation, and organic solvent residues resulting from solvent extraction and distillation, but also overcome the disadvantages of pressing methods like the volatilization of essential oils and color darkening. Zhang et al. [60] studied the influencing factors in the supercritical $\mathrm{CO}_{2}$ extraction of Litsea cubeba essential oil, where the particle size, $\mathrm{CO}_{2}$ flow rate, extraction pressure, temperature, and time were optimized to obtain the highest extraction ratio. Although supercritical $\mathrm{CO}_{2}$ extracts could maintain the naturalness of the raw materials, there are still some limitations for wide industrial applications of this technique like poor robustness of the early commercial equipment, lack of standard extraction procedures, difficulties in extracting polar compounds, and inefficiency in clean-up [63].

\subsection{Bioactivities of Litsea cubeba Essential Oils}

In China, Litsea cubeba is also called 'Bì Chéng Qié', which has been commonly used as a traditional herbal medicine. From the perspective of traditional Chinese medicine, fruits, root bark, and leaves from Litsea cubeba can be used as medicines to treat stomach pain, vomit, fever, snake bites, swelling, cholera, and detoxification. Modern pharmacology studies have shown that Litsea cubeba extracts have a variety of biological activities such as antioxidant, antimicrobial, anti-inflammatory, anti-tumor, and insecticide, which gives it the potential to be widely used in the field of agriculture, medicine, food, flavor, and fragrance, etc.

\subsubsection{Antimicrobial Activity}

Citral in Litsea cubeba essential oil was firstly found to have a strong inhibitory effect on bacteria [64]. Many experiments have shown that Litsea cubeba essential oil had a broadspectrum bacteriostasis and a certain antifungal effect. Minimal inhibitory concentrations (MICs) of Litsea cubeba essential oil against different bacteria and fungi are summarized in Table 3, which shows a great potential for wide applications ranging from grain storage to preservation of fruit, aquatic and cosmetic products, etc. 
Table 3. Minimal inhibitory concentrations (MICs) of Litsea cubeba essential oil against different bacteria and fungi.

\begin{tabular}{|c|c|c|c|c|}
\hline \multicolumn{2}{|l|}{ Organism } & \multirow{2}{*}{$\operatorname{MIC}[\mu \mathrm{g} / \mathrm{mL}]$} & \multirow{2}{*}{ Method } & \multirow{2}{*}{ References } \\
\hline Bacteria & Gram-Type & & & \\
\hline Enterohemorrhagic Escherichia coli (EHEC) & - & 500 & Double dilution & [65] \\
\hline $\begin{array}{l}\text { Methicillin-resistant Staphylococcus aureus } \\
\text { (MRSA) }\end{array}$ & + & 500 & Broth micro-dilution & [66] \\
\hline Staphylococcus aureus & + & 80 & Broth micro-dilution & \\
\hline Bacillus cereus & + & 40 & Broth micro-dilution & \\
\hline Bacillus subtilis & + & 40 & Broth micro-dilution & [67] \\
\hline Salmonella typhimurium & - & 20 & Broth micro-dilution & \\
\hline Listeria monocytogenes & + & 2500 & Broth micro-dilution & [49] \\
\hline Salmonella & - & 625 & Double dilution & \\
\hline Shigella & - & 625 & Double dilution & [68] \\
\hline Pseudomonas aeruginosa & - & 620 & Broth micro-dilution & \\
\hline Enterococcus faecalis & + & 600 & Broth micro-dilution & [69] \\
\hline Shewanella putrefaciens & - & 0.5 & Broth micro-dilution & [70] \\
\hline Staphylococcus albus & + & $11.88-23.75$ & Broth-dilution & [71] \\
\hline Vibrio parahaemolyticus & - & 750 & Broth-dilution & [72] \\
\hline \multicolumn{5}{|l|}{ Fungi } \\
\hline Alternaria alternaria & & 0.05 & Agar-dilution & [73] \\
\hline Aspergillus flavus & & 0.5 & Agar-dilution & [74] \\
\hline Aspergillus niger & & 5 & Agar-dilution & [73] \\
\hline Fusarium oxysporum & & 0.49 & Agar-dilution & [75] \\
\hline Fusarium moniliforme & & 0.5 & Agar-dilution & \\
\hline Fusarium solani & & 0.5 & Agar-dilution & [7/3] \\
\hline Galactomyces candidum & & 1.0 & Agar-dilution & [76] \\
\hline Candida albicans & & 700 & Broth micro-dilution & [69] \\
\hline Lactobacillus plantarum & & 1500 & Broth-dilution & [72] \\
\hline Malassezia furfur & & $2367.61 \pm 688.29$ & Broth micro-dilution & {$[77]$} \\
\hline
\end{tabular}

You et al. [78] found that there were many endophytic bacteria in Litsea cubeba plants. Such bacterial population was also significant for the increase of Litsea cubeba essential oil yield and citral content in oil, which could enhance its bacteriostatic effect. Wang et al. [75] studied the bacteriostatic effect of essential oils from three species of May Chang tree, among which the content of essential oil from Litsea cubeba (Lour.) Pers. was significantly higher than those from Litsea mollis Hemsl. and Litsea cubeba var. formosana. Moreover, its bacteriostatic effect on Fusarium oxysporum f. sp. fordii 1, Escherichia coli, and Listeria monocytogenes was also better than the other two Litsea essential oils, which could be potentially developed for antibacterial and antiseptic products. In addition, the contents of citral (70-90\%) and linalool were shown to have a significant positive correlation with inhibition rate.At present, studies about bacteriostatic mechanism of Litsea cubeba essential oils mainly focus on the destruction of cell's biological structure and the inhibition of their normal life activities. Litsea cubeba essential oil could destroy the cell membrane of methicillin-resistant Staphylococcus aureus (MRAS), resulting in the loss of biological macromolecules in cells. Moreover, it could inhibit the respiratory metabolism of MRSA through reducing the activity of glucose-6-phosphate dehydrogenase, a key regulatory enzyme in hexose monophosphate pathway (HMP). Besides, the main component citral could also form a chimera with DNA of MRSA to inhibit the biological activity of bacteria [66]. Similarly, the antibacterial mechanism of Litsea cubeba essential oil on Enterohemorrhagic Escherichia coli O157:H7 was reported to be related to increasing the permeability of cell membranes, inhibiting respiratory metabolism, hindering the normal function of nucleic acids, and reducing the pathogenicity by inhibiting the transcription level of its main virulence genes [65]. Ju et al. [79] pointed out that the synergistic inhibitory mechanism of eugenol and citral against Penicillium roqueforti was to destroy the cell membrane of mycelia; affect the conformation of membrane protein and the fatty acid composition of the 
cell membrane; and inhibit the enzyme activity, energy metabolism, and gene expression of key molecules in the tricarboxylic acid cycle (TCA) pathway, which led to the disorder of respiration and energy metabolism of Penicillium roqueforti, and apoptosis in the end.

Litsea cubeba essential oil could also be prepared for coating materials with chitosan, which helped to reduce the consumption of nutrients and delay the decay of fruits such as kumquat and strawberry. Thielmann et al. [80] coated food packaging films with polyvinyl acetate (PVA), containing different concentrations of citral or Litsea cubeba essential oil, which showed obvious bactericidal effects on Escherichia coli and Staphylococcus aureus when dry matter (DM) was standardized to $20 \% w / w$ as the sum of PVA and antimicrobial compound. The headspace packaging for the $20 \%$ DM coating also had an inhibitory effect on the growth of yeast and mold in the strawberry application trial.

\subsubsection{Antioxidant Activity}

Litsea cubeba essential oil could be used as a good natural antioxidant in food. However, it is highly volatile and unstable in light or upon heating. Hwang et al. [81] evaluated the DPPH free radical scavenging ability, $\mathrm{H}_{2} \mathrm{O}_{2}$ scavenging activity, and inhibition activity of lipid peroxidation of Litsea cubeba essential oil, which proved the significant in vitro antioxidant activity Litsea cubeba essential oil. Gogoi et al. [67] reported that methyl heptanone $(30.9 \%)$ and sabinene $(25.22 \%)$ were the main components in fruit and leaf essential oils of Litsea cubeba Pers. from Northeast India, respectively. Both essential oils showed strong concentration-dependent antioxidant activities, where Litsea cubeba fruit essential oil had better antioxidant and anti-inflammatory activities than that from leaves. She et al. [82] studied chemical composition, antimicrobial, and antioxidant activities of Litsea cubeba essential oils collected in different months, which found that the yield of Litsea cubeba essential oils collected in June, July, and August was 3.47\% containing 13 components, $5.02 \%$ containing 17 components, and $5.64 \%$ containing 17 components, respectively. Neral and geranial accounting for $54.76 \%$ were the main components. The essential oil from July had the highest $\mathrm{OH}$. scavenging activity while that from August had the highest DPPH. scavenging activity and ferric-reducing antioxidant activity.

Although Litsea cubeba essential oil has been proven to have a considerable antioxidant activity, its particular characteristics like low water solubility, high volatility, and photosensitivity limit its application range. Wang et al. [83] used ultrasonic emulsification to formulate a highly stable and water-dispersible nanoemulsion of Litsea cubeba essential oil with improved biological activities like antibiofilm, antioxidant, and antimicrobial properties.

\subsubsection{Anthelmintic Activity}

Many components in Litsea cubeba essential oil such as citral, aromatic alcohol, $\beta$ pinene, and citronellal have repelling or lethal effects against mosquitoes. Chen et al. [84] found that Litsea cubeba essential oil had a good repellent activity and larvicidal activity against Aedes albopictus, which are closely related to its chemical composition. Therefore, the Litsea cubeba essential oil may be used for alternative natural repellent to the synthetic DEET.

The insecticidal activity of essential oils from 26 plant species was compared using a fumigation bioassay, where Litsea cubeba essential oil was observed with strong insecticidal activity against Reticulitermes speratus Kolbe [85]. When Litsea cubeba essential oil is used as insecticide in the field or granary, it can kill many kinds of grain pests, such as rice weevil, grain weevil, bean weevil, gnawing beetle, Rhizopertha dominica, and so on. Repellent effects of Litsea cubeba essential oil on various growth forms of mosquitos and insects are showed in Table 4. 
Table 4. Repellent effects of Litsea cubeba essential oil on various growth forms of mosquitoes and insects.

\begin{tabular}{|c|c|c|c|}
\hline Species & Morphology & Experimental Remarks & References \\
\hline Aedes aegypti (L.) mosquitoes & Adult & $\begin{array}{c}24 \mathrm{~h} \text { direct contact mortality: } 2.3-20.4 \% \\
24 \mathrm{~h} \text { non-contact mortality: } 0-14.3 \%\end{array}$ & [86] \\
\hline Aedes albopictus & $\begin{array}{l}\text { Larva (the fourth-instar) } \\
\text { Pupae } \\
\text { Adult }\end{array}$ & $\begin{array}{c}24 \mathrm{~h} \mathrm{LC}_{50}: 82.48 \mu \mathrm{g} / \mathrm{mL} \\
24 \mathrm{~h} \mathrm{LC} \mathrm{LC}_{50}: 122.92 \mu \mathrm{g} / \mathrm{mL} \\
73.94 \text { percentage repellency at } 20 \mathrm{~min}(2.0 \mu \mathrm{L})\end{array}$ & $\begin{array}{l}{[84]} \\
{[87]}\end{array}$ \\
\hline Lasioderma serricorne & Adult & $\begin{array}{l}\text { Contact toxicity } 24 \mathrm{~h} \mathrm{LC} \mathrm{L}_{50}: 27.33 \mu \mathrm{g} / \mathrm{adult} \\
\text { Fumigant toxicity } 24 \mathrm{~h} \mathrm{LC} 50: 22.97 \mathrm{mg} / \mathrm{L}\end{array}$ & \multirow{2}{*}{ [88] } \\
\hline Liposcelis bostrychophila & Adult & $\begin{array}{l}\text { Contact toxicity } 24 \mathrm{~h} \mathrm{LC}_{50}: 71.56 \mu \mathrm{g} / \mathrm{cm}^{2} \\
\text { Fumigant toxicity } 24 \mathrm{~h} \mathrm{LC}_{50}: 0.73 \mathrm{mg} / \mathrm{L}\end{array}$ & \\
\hline Bursaphelenchus Xylophilus & Adult & $24 \mathrm{~h} \mathrm{LC}_{50}: 0.504 \mathrm{mg} / \mathrm{mL}$ & [89] \\
\hline $\begin{array}{l}\text { Liposcelis entomophila } \\
\text { Enderlein }\end{array}$ & Adult & $24 \mathrm{~h} \mathrm{LC}_{50}: 6.23 \mu \mathrm{L} / \mathrm{L}$ & {$[90]$} \\
\hline Tribolium castaneum & Adult & $1.5 \mathrm{~g} / \mathrm{cm}^{2}$ repellent rate $(12 \mathrm{~h}): 81.26 \%$ & [91] \\
\hline Trichoplusia ni & Larva (the third-instar) & $\begin{array}{c}24 \mathrm{~h} \mathrm{LC} \mathrm{LC}_{50}: 112.5 \mu \mathrm{g} / \text { larva } \\
\text { Contact toxicity } 12 \mathrm{~h} \mathrm{LC} \mathrm{LC}_{50}: 0.932 \mu \mathrm{g} / \mathrm{cm}^{2}\end{array}$ & [92] \\
\hline Luciaphorus perniciosus & Adult & $\begin{array}{l}99 \mu \mathrm{g} / \mathrm{cm}^{2} \text { showed the highest toxicity } \\
\text { causing } 97.5 \pm 4.1 \% \text { mortality at } 12 \mathrm{~h} \\
\text { Fumigation } 12 \mathrm{~h} \mathrm{LC} \mathrm{L}_{50}: 0.166 \mu \mathrm{g} / \mathrm{cm}^{3}\end{array}$ & [93] \\
\hline Anopheles stephensi & Adult & $\begin{array}{l}\text { The protection period: } 480 \mathrm{~min} ; \\
100 \text { percentage repellency }\end{array}$ & \multirow{2}{*}{ [94] } \\
\hline Culex quinquefasciatus & Adult & $\begin{array}{l}\text { The protection period: } 480 \mathrm{~min} ; \\
100 \text { percentage repellency }\end{array}$ & \\
\hline
\end{tabular}

Wu et al. [87] found that the optimal formula of the repellent liquid was the blending of Litsea cubeba oil (10\%), Mentha arvensis oil (10\%), Tween $80(5 \%)$, vanillin $(5 \%)$, and absolute ethyl alcohol (70\%), in which effective sterilizing time for hand skin was $4 \mathrm{~h}$. The blending of Litsea cubeba and clove essential oil $(40: 60 \mathrm{v} / \mathrm{v})$ had the strongest fumigation activity against female adults of Liposcelis entomophila (Enderlein), which showed significant synergism with the co-toxicity factor of 49.42 [90].

\subsubsection{Other Bioactivities}

Apart from the above, other bioactivities of Litsea cubeba essential oil were studied as well. The inhibitory effect of Litsea cubeba essential oil on dendritic cell activation was studied, as well as the in vivo immunosuppressive effects in mice [95]. Litsea cubeba essential oil was found to inhibit both the production of TNF- $\alpha$ and cytokine IL-12 in lipopolysaccharide-stimulated dendritic cells with a dose-dependent manner, and the hypersensitivity reaction and T-cell infiltration in mice, indicating that Litsea cubeba essential oil can potentially be applied in the treatment of contact hypersensitivity, inflammatory diseases, and autoimmune diseases.

Citral, as the major component in Litsea cubeba essential oil, could significantly prolong the incubation period of asthma induced by choline phosphate histamine spray, which had certain antiasthmatic, antitussive, and expectorant effects [96]. Furthermore, Litsea cubeba essential oil could significantly inhibit the pain response caused by acetic acid and high fever with an analgesic rate of more than 30\% [97]. It also had anti-inflammatory and anti-cancer activities [98], which might be used as a new plant resource to prevent such diseases. Gogoi et al. [67] found that essential oils from Litsea cubeba fruit and leaves had strong in vitro anti-inflammatory activities, which were relatively low compared to the standard anti-inflammatory drug diclofenac sodium. Choi et al. [99] found that Litsea cubeba essential oil could inhibit the production of inflammation mediators (i.e., NO and $\mathrm{PGE}_{2}$ ) in RAW264.7 macrophages activated by lipopolysaccharide, and there was no obvious cytotoxicity when the concentration was lower than $0.01 \mathrm{mg} / \mathrm{mL}$. Similarly, Zhong et al. [100] found that the NO inhibition rate was $\geq 50 \%$ when the concentration of Litsea cubeba essential oil was 31.25-62.50 $\mu \mathrm{g} / \mathrm{mL}$ through using mouse macrophage cells (RAW264.7) and murine hepatoma cells as models. Quinone reductase could inactivate 
carcinogens through stress reaction, thus the quinone reductase activity was evaluated as an anti-cancer index, which was induced to double when the concentration of Litsea cubeba essential oil was $15.63-31.25 \mu \mathrm{g} / \mathrm{mL}$.

The mainstream of future beauty market should be natural, safe, and functional. Huang [101] compared the in vitro tyrosinase inhibition activity of three volatile oils (Litsea cubeba, citronella and clove) and their main components, which showed that Litsea cubeba essential oil and its main component citral had a good performance with an inhibition rate of $50 \%$, which showed its development potential in the field of cosmetics and skin care. Furthermore, Litsea cubeba essential oil could prolong pentobarbitone-induced mouse sleeping time and had anxiolytic activity and potent analgesic activity [102]. Besides, the inhalation of Litsea cubeba essential oil could significantly improve the total mood disturbance and reduce the confusion among the healthy human subjects and the salivary cortisol level at a notable level [103]. This indicated that Litsea cubeba essential oil could be used in aromatherapy as a complementary and alternative therapy for health, which is favorable to improve physical, mental, and emotional states [104].

\subsection{Purification of Litsea cubeba Essential Oil and Its Derivatives}

Citral is the main biologically active component in Litsea cubeba essential oils, which has two configurations including geranial ( $\alpha$-citral) and neral ( $\beta$-citral). It is a light yellow volatile oily liquid with a lemon flavor, which is authorized as a food-grade flavor in China. Citral is mainly used in the preparation of lemon, citrus and assorted fruit-type food flavors, dishwashing detergents, soaps, toilet water, and flavoring agents. Also, it can be an intermediate for formulating and synthesizing high value-added functional ingredients, which are often used in perfumes and nutraceuticals.

\subsubsection{Purification of Litsea cubeba Essential Oil}

Citral can be purified from Litsea cubeba essential oil in many ways. The traditional steam distillation method has been gradually phased out due to its low utilization rate of raw material and the low purity of the end-product obtained. Conventional chemical method with the addition of sodium sulfite has many deficiencies such as low extraction rate, long reaction time, and the lye contamination after reaction. Liu et al. [105] reduced the original chemical reaction time 20 times with the help of microwave heating, in which temperature and other conditions were flexible and easy to control.

As shown in Table 5, Peng et al. [106] and Fu et al. [107] investigated the effect of phase transfer catalyst type and dosage, reaction time, and temperature on the yield and purity of citral, where the final yield of citral under optimal conditions was 73.47\% with the purity of $85.49 \%$. Atmospheric distillation has a high evaporation temperature, and substances with high boiling points are prone to reactions such as decomposition, oxidation, and polymerization. Therefore, vacuum distillation could reduce the boiling point of components in Litsea cubeba essential oil, where the reaction proceeded quickly under high vacuum and low temperature without any negative effects on yield, aroma, and quality [108]. Molecular distillation conditions were optimized to improve the yield and purity of citral from Litsea cubeba essential oil $[109,110]$. This technology largely maintains the naturalness of the raw materials, which is an efficient process for industrial applications.

\subsubsection{Citral-Derived Fragrances}

There are carbonyl groups and double bonds in the structure of citral, which are prone to chemical reactions such as addition, condensation, cyclization, and oxidation. In other words, citral can be a natural synthon for a variety of important perfume compounds with a purity as high as above $90 \%$ (Figure 2); this synthetic technique is of great significance to the future development and utilization of Litsea cubeba resources. 
Table 5. Purification technologies of citral.

\begin{tabular}{|c|c|c|c|}
\hline Methods & Conditions & Experimental Remarks & References \\
\hline \multirow{2}{*}{$\begin{array}{l}\text { Sodium sulfite chemical } \\
\text { addition method }\end{array}$} & $\begin{array}{l}\text { DMSO as phase transfer catalyst: } 5 \% \text { of } \\
\text { citral material; } \\
\text { Time: } 3.5 \text { h, Temperature: } 10{ }^{\circ} \mathrm{C} \text {. }\end{array}$ & $\begin{array}{l}\text { The citral yield was } 73.47 \% \\
\text { and the purity was } 85.49 \% \text {. }\end{array}$ & [106] \\
\hline & $\begin{array}{c}\text { Methylated- } \beta \text {-cyclodextrin }(\mathrm{RM}-\beta-\mathrm{CD}) \text { as } \\
\text { phase transfer catalyst: } 0.65 \% \text { of } \\
\text { citral material; } \\
\text { Time: } 3.3 \mathrm{~h} \text {, Temperature: } 15^{\circ} \mathrm{C} \text {. }\end{array}$ & $\begin{array}{c}\text { The citral yield was } 86.6 \% \text { and } \\
\text { the purity was } 96.5 \% \text {. }\end{array}$ & [107] \\
\hline
\end{tabular}

Pretreatment: dehydration,

magnetization, filtration, and deoxidation;

Vacuum distillation

Vacuum degree: $10 \mathrm{~mm} \mathrm{Hg}$, tower kettle temperature: $<100{ }^{\circ} \mathrm{C}$;

The purity of citral was $97.9 \%$, and the yield was $90.8 \%$.

The first fractionation column top temperature $<65{ }^{\circ} \mathrm{C}$, reflux ratio $2: 1$;

The second fractionation column top temperature $<90^{\circ} \mathrm{C}$, reflux ratio 3:1.

Film scraping speed: 400 r/min; Feeding amount: $1 \mathrm{~L}$

Cooling water temperature: $12^{\circ} \mathrm{C}$;

Distillation temperature: $55^{\circ} \mathrm{C}$;

Distillation pressure: $0.18 \mathrm{kPa}$;

Molecular distillation Material flow: $15 \mathrm{~mL} / \mathrm{min}$.

The purity of citral was up to $98 \%$ and the yield rate was up to $77.2 \%$.

Film scraping speed: $370-390 \mathrm{r} / \mathrm{min}$;

Cooling water temperature: $4-5^{\circ} \mathrm{C}$;

Distillation temperature: $45^{\circ} \mathrm{C}$;

Distillation pressure: $0.15 \mathrm{kPa}$; Material flow: 1 drop/s.

The content of citral was

increased from $79.61 \%$ to

$95.08 \%$, and the yield of citral was $80.02 \%$.

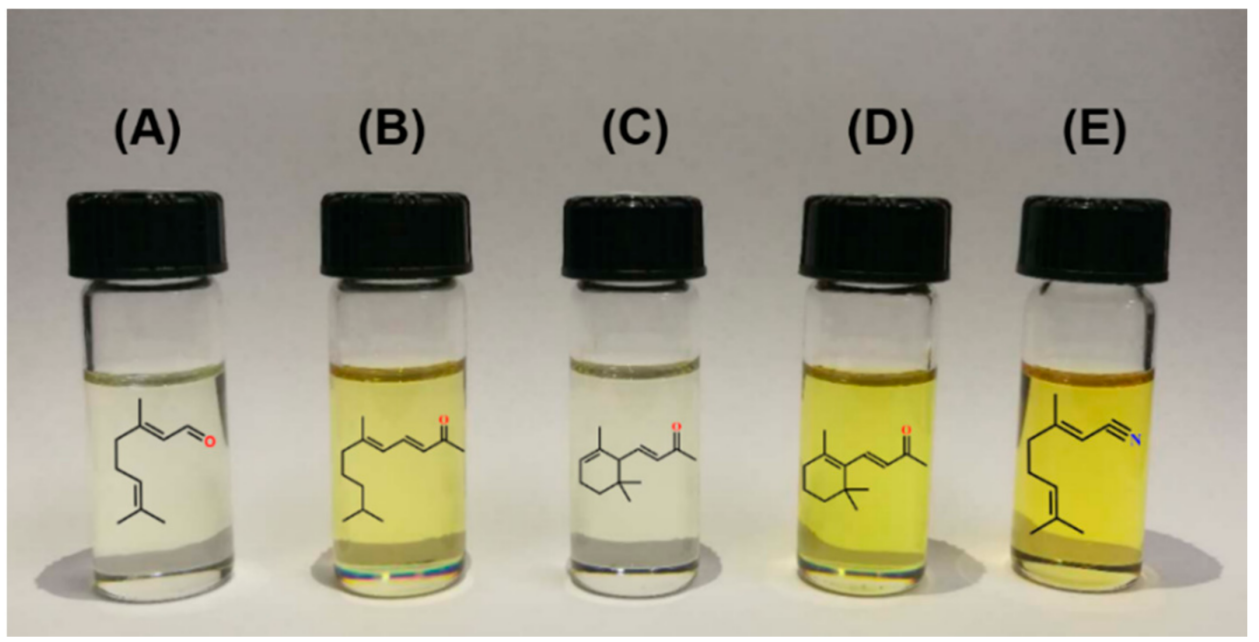

Figure 2. Citral-derived fragrances from Litsea cubeba (LC) essential oils: (A) purified LC essential oils; (B) pseudoionone; (C) $\alpha$-ionone; (D) $\beta$-ionone; (E) lemonile.

Ionone is an oily liquid with color ranging from colorless to slightly yellow and a strong violet floral aroma. It is an indispensable raw material or intermediate in the aromatization, in which synthesized products can be divided into $\alpha$-ionone, $\beta$-ionone, and uncommon $\gamma$-ionone. $\alpha$-ionone is often used for the formulation of perfume, and $\beta$-ionone can be used for the synthesis of vitamin A. Citral was used to undergo aldol condensation with acetone under the catalysis of $\mathrm{NaOH}$ to form pseudoionone, which was then cyclized to produce ionone catalyzed by phosphoric acid with a total yield of 
81.4\% [111]. Pseudoionone could also be synthesized by solid base $\left(\mathrm{LiOH} \cdot \mathrm{H}_{2} \mathrm{O}\right)$ catalysis, in which the conversion rate of ciral and the selectivity to pseudoionone under optimal reaction conditions were $98.9 \%$ and $97.7 \%$, respectively [112]. Lemonile has a strong and persistent lemon aroma with a higher thermal stability than citral. Citral purified from Litsea cubeba essential oils was reacted with hydroxylamine sulfate to form citrate oxime. Under the microwave irradiation, Citral could directly produce lemonile with an average yield of $90.7 \%$ using polyethylene glycol 600 as the phase transfer catalyst [113].

Irone is a high-value product used in perfumes, cold cream and cosmetics, cigarettes, soap, and other daily necessities, which has a similar soft sweet smell to iris and violet. The chemical synthesis of irone is mainly accomplished through the citral-pseudoionone pathway. In dilute alkali solution, citral and acetone are condensed to form pseudoionone, which is synthesized by methyl localization, and finally by cyclization. Liu et al. [114] made a break-through in the synthesis of irone, where pseudoirone was firstly formed from methylated pseudoionone, and then cyclized to obtain irone, resulting in a total yield up to $47.9 \%$ but with no specific methyl localizer and cyclizing agent reported.

Vitamin A is indispensable for maintaining the normal metabolism of human body, but the extraction process from animal tissues is complicated and costly. Therefore, it is usually chemically synthesized as vitamin A carboxylates mainly through two routes. Roche in Switzerland took $\beta$-ionone as the starting material and completed the synthesis of vitamin A acetate through Darzens reaction, Grignard reaction, selective hydrogenation, hydroxyl bromination, and dehydrobromination. BASF in Germany also used $\beta$-ionone as the starting material and performed Grignard reaction with acetylene to produce acetylene- $\beta$ ionol, and then selectively hydrogenated to obtain ethylene- $\beta$-ionol. After Wittng reaction, ethylene- $\beta$-ionol condensed with C5 aldehyde to generate vitamin A acetate, which was catalyzed by sodium alkoxide.

\section{Biorefinery after Litsea cubeba Essential Oil Production}

Litsea cubeba essential oil processing generates numerous residues like kernels and pomaces, which are mostly discarded or burned as wastes, resulting in high environmental burden. Hence, how to transform these wastes to value-added by-products in a sustainable way is the key to open the gate of Litsea cubeba industrial market.

\subsection{Litsea cubeba Kernel Oil}

Kernels after the extraction of Litsea cubeba essential oil still contain around $40 \%$ oil content with high saturation level $(\approx 74 \%)$, consisting of mainly medium chain fatty acids like lauric acid and capric acid. The Litsea cubeba kernel oil seems to be a promising new source of lauric acid, whose physicochemical properties are comparable to that of coconut oil [115].

As shown in Table 6 [116-121], the traditional mechanical method had a low yield with a long pressing time, in which residues still contained a certain amount of oil. The organic solvent extraction is the common industrial method, in which the oil yield could be improved with a lighter color. Aqueous extraction is a traditional method unique to China, whose principle is to separate oil and hydrophilic non-oil components (e.g., protein) based on their differences in affinity to oil and water and specific gravity. This method is easy to operate and can be enhanced with the assistance of microwave or other innovative techniques, which require less equipment with no worry about organic solvent residue problems. The effect of different solvents on the extraction of Litsea cubeba kernel oil demonstrated that cyclopentyl methyl ether could be the best substitute to $n$-hexane with comparable extraction efficiency and selectivity [121]. Supercritical $\mathrm{CO}_{2}$ extraction as a green extraction technology was also conducted to optimize the influencing parameters, which showed a high extraction efficiency. However, the high initial cost and professional requirements should be taken into consideration for a start-up industrialization. 
Table 6. Extraction methods and technology of Litsea cubeba kernel oils.

\begin{tabular}{cccc}
\hline Methods & Process Conditions & Experimental Remarks & References \\
\hline & Press in a single screw press, collect & The crude oil yield was 26.2\%, \\
Mechanical pressing & and filter the crude oil, then store it in a & which was reduced to 21.2\% after & simple refining. \\
& $4{ }^{\circ} \mathrm{C}$ refrigerator. & [116] & \\
\hline
\end{tabular}

Refluxing with petroleum ether $\left(60-90^{\circ} \mathrm{C}\right)$;

Solvent reflux method

Particle size of material: less than $0.15 \mathrm{~mm}$

Solid-liquid ratio at 1:14 (g:mL); Extraction temperature and time: $80^{\circ} \mathrm{C}$, $2.0 \mathrm{~h}$.

\begin{tabular}{|c|c|c|c|}
\hline \multirow{2}{*}{ Microwave-assisted extraction } & $\begin{array}{l}\text { Microwave time: } 65 \mathrm{~min} ; \\
\text { Extraction temperature: } 78^{\circ} \mathrm{C} ; \\
\text { Solid-liquid ratio at } 1: 14.5 ; \\
\text { Microwave power: } 545 \mathrm{~W} \text {. }\end{array}$ & $\begin{array}{l}\text { The aqueous extraction rate of } \\
\text { kernel oil is } 29.36 \% \text {. The content } \\
\text { of lauric acid, capric acid and } \\
\text { oleic acid is }>50 \%, 8.512 \% \text { and } \\
10.603 \% \text {, respectively. }\end{array}$ & [118] \\
\hline & $\begin{array}{l}\text { Microwave time: } 63 \mathrm{~min} ; \\
\text { Extraction temperature: } 69^{\circ} \mathrm{C} \text {; } \\
\text { Solid-liquid ratio at } 1: 16 \text { (g:mL); } \\
\text { Microwave power: } 337 \mathrm{~W} .\end{array}$ & $\begin{array}{l}\text { The extraction rate of kernel oil is } \\
37.42 \% \text {, which improved by } \\
30.11 \% \text { compared to } n \text {-hexane } \\
\text { reflux method. The content of } \\
\text { lauric acid is the highest }(31.36 \%) \text {. }\end{array}$ & [119] \\
\hline Supercritical $\mathrm{CO}_{2}$ extraction & $\begin{array}{l}\text { Extraction time: } 80 \mathrm{~min} ; \\
\text { Extraction temperature: } 45^{\circ} \mathrm{C} ; \\
\text { Extraction pressure: } 25 \mathrm{MPa} ; \\
\text { Flow rate of carbon dioxide: } 220 \mathrm{~L} / \mathrm{h} \text {. }\end{array}$ & $\begin{array}{l}\text { The extraction rate is above } 84.5 \% \text {, } \\
\text { dehulling may increase the } \\
\text { extraction rate. }\end{array}$ & [120] \\
\hline Alternative solvent extraction & $\begin{array}{l}\text { Solid-liquid ratio at } 1: 20 \text { (g:mL); } \\
\text { Heating under reflux for } 3 \mathrm{~h} ; \\
\text { Extraction temperature: solvents' } \\
\text { boiling point. }\end{array}$ & $\begin{array}{l}\text { Green solvents were superior to } \\
\text { alcoholic solvents with higher oil } \\
\text { yields. Alternative solvents to } \\
n \text {-hexane extracted more } \\
\text { micronutrients (e.g, tocopherol, } \\
\text { sterol and phenolic compounds) } \\
\text { resulting in better } \\
\text { antioxidant activities. }\end{array}$ & [121] \\
\hline
\end{tabular}

\subsubsection{Purification of Fatty Acids and Derived Green Surfactants}

Litsea cubeba kernel oil contains more saturated fatty acids than unsaturated fatty acids, where lauric acid content is the highest accounting for about $40-60 \%$ of total fatty acids, followed by decanoic acid accounting for about $10-12 \%$. Generally, distillation and freeze-pressing are used to prepare lauric acid, which are difficult to scale up due to high cost and poor quality of products. Zhou et al. [122] refined the Litsea cubeba kernel oil through acid refining, saponification, and acidification hydrolysis to obtain mixed fatty acids, where high-purity lauric acid $(>98 \%)$ was then prepared under vacuum and optimal mixed solvent crystallization. Apart from the medium chain saturated fatty acids $(\approx 72 \%)$, there are also mono- $(\approx 22 \%)$ and poly- $(\approx 6 \%)$ unsaturated fatty acids, which are quite different from other lauric oils [120]. Significantly, a considerable content of lauroleic acid $(\approx 7 \%)$ was firstly found in Litsea cubeba kernel oil in addition to oleic acid $(\approx 12 \%)$ and linoleic acid $(\approx 6 \%)$. This special fatty acid may deserve more studies to find its characteristics and functionality.

Surfactant refers to a fine chemical with hydrophilic (i.e., hydroxyl, sulfate, sulfonate) and lipophilic or atmophile non-polar (i.e., hydrocarbon group) groups that can significantly change the liquid surface tension or interfacial tension between two phases. Natural fatty acids in Litsea cubeba kernel oil could be purified as a chemical basis for the synthesis of anionic, cationic, and nonionic surfactants. Lauric acid as the main medium chain fatty acid from Litsea cubeba kernel oil could be a green synthon for various eco-friendly surfactants 
such as carboxylate, lauronitrile dodecane nitrile, alkanolamide, $n$-laureylethylenediamine triacetic acid, etc. [123]. Lauryl aldehyde and laurinol derived from Litsea cubeba kernel oil could react together to synthesize cyclic acetal type surfactants. Compared to traditional surfactants, this new type of surfactant greatly improved both chemical and biological degradability, as well as surface activity [124].

\subsubsection{Biodiesel Production from Kernel Oil}

Since the world as an integral whole faces common challenges like depletion of fossil resources, global warming, and an increasing population, plant-based chemicals have gradually become the mainstream toward a petroleum-free sustainable future [125]. Biodiesel is a kind of green renewable energy that has been studied for years.

Litsea cubeba kernel oil with a considerable oil content is theoretically feasible to be the biodiesel feedstock. As a non-food vegetable oil, using Litsea cubeba kernel oil to produce biofuels conforms to the concept of Green Chemistry without any competition to foods. Wang et al. [126] used the hydrothermal liquefaction to partially convert into bio-oil with a yield of up to $56.9 \mathrm{wt}$.\%, where temperature was found as the most important factor to the final yield. Moreover, $\mathrm{Na}_{2} \mathrm{CO}_{3}$ loading was beneficial to the conversion of the feedstock but adverse to the polymerization pathway of bio-oil formation. Zhang et al. [127] used Litsea cubeba kernel oil and ethanol to produce biodiesel with solid acid catalyst $\mathrm{SO}_{4}{ }^{2-} / \mathrm{Fe}_{2} \mathrm{O}_{3}$ $\mathrm{TiO}_{2}$. Such a catalyst could improve the reaction activity with the biodiesel yield of $44.9 \%$ under the optimal conditions, i.e., molar ratio of ethanol to Litsea cubeba kernel oil (16:1), catalyst dosage $(10 \mathrm{wt} \%)$, reaction time $(8 \mathrm{~h})$, and ethanol refluxing temperature $\left(78{ }^{\circ} \mathrm{C}\right)$. Recently, zinc supported on zirconia heterogeneous catalyst $\left(7 \% \mathrm{Zn} / \mathrm{ZrO}_{2}\right)$ was successfully synthesized and performed the best for the biodiesel production from Litsea cubeba kernel oil through transesterification under optimal conditions, i.e., methanol to oil molar ratio $(8: 1)$, catalyst loading $(5 \mathrm{wt} \%)$, reaction temperature $\left(120{ }^{\circ} \mathrm{C}\right)$, reaction time $(12 \mathrm{~h})$ and stirring rate $(400 \mathrm{rpm})$ [128].

\subsubsection{Biolubricant Base Oil}

Traditional lubricating oils derived from non-renewable mineral raw materials are poorly biodegradable, which are likely to have a serious impact on ecological balance. In contrast, plant oil-based lubricants can be biodegraded quickly and completely with low ecotoxicity [129]. Therefore, the development of ecofriendly biolubricating oils has attracted more attention. According to the ASTM (American Society for Testing and Materials) test, plant oils from rapeseed, soybean, sunflower, and palm with long-chain fatty acids can be used as bio-based raw materials, which can ensure good lubricity and low environmental impact. Nevertheless, using these oils as feedstock may lead to competition with food supply and poor oxidative stability of biolubricant base oils. Recently, Litsea cubeba kernel oil demonstrated itself as a promising medium-chain saturated fatty acid feedstock for biolubricant-based oil synthesis [130]. The fatty acid methyl ester (FAME) of Litsea cubeba kernel was prepared through decolorization, glycolysis, and methanolysis, which was then transesterified with trimethylolpropane (TMP) to produce trimethylolpropane fatty acid trimester (TFATE) under optimal conditions (Figure 3). The purified TFATE product could achieve good oxidative stability and low-temperature performance qualified by ISO VG 32 standard.

\subsection{Litsea cubeba Protein}

After oil expression, the considerable protein content in the oil cake is often a matter of concern. The extraction rate of Litsea cubeba protein reached $31.03 \%$ under optimal conditions (i.e., solid-liquid ratio 1:1.5, $\mathrm{pH}$ value 11 , temperature $35^{\circ} \mathrm{C}$, and time $60 \mathrm{~min}$ ), where the protein content in the crude protein extract was 75\% [131]. The solubility, foaming ability, and foam stability were lower at acidic $\mathrm{pH}$ condition. The water holding ability was higher than that of commercial soybean protein isolate when the temperature was below $60^{\circ} \mathrm{C}$. 


\section{Biorefinery from industrial waste to biolubricant base oil}

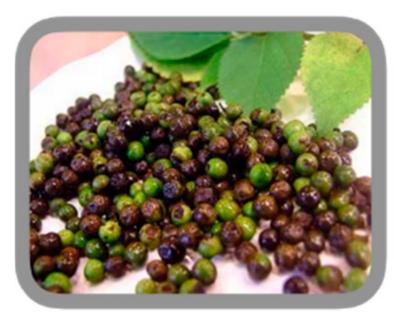

Litsea cubeba (Lour.) Pers.

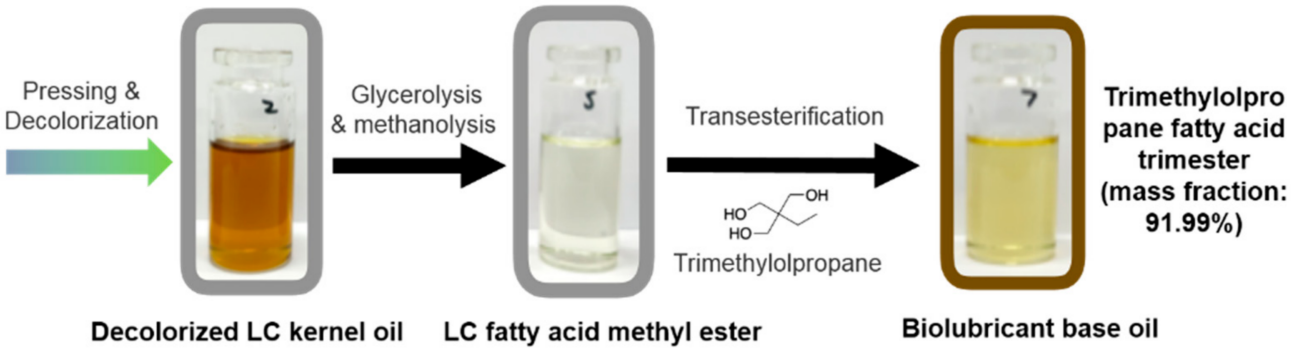

Decolorized LC kernel oil LC fatty acid methyl ester
Biolubricant base oil

Figure 3. Sustainable biorefinery route for the production of biolubricant base oils from Litsea cubeba (LC) kernels as waste residues after the essential oil production.

\subsection{Litsea cubeba Pomace}

Litsea cubeba pomace as a waste residue has the potential to be a feed resource due to its comparable nutrient contents to other common fodders, and the trace amount of residual essential oil, whose biological activities may beneficial to the animal growth. Zhang et al. [132] studied metabolic energy and the utilization rate of common nutrients and amino acids on Litsea cubeba pomace in feeding roosters and ducks, which showed that the apparent utilization rate of crude Litsea cubeba protein and fat was $>50 \%$ and $>80 \%$, respectively. Compared to roosters, ducks had a higher utilization rate of protein and amino acids but with a lower utilization rate of crude fat and fiber, indicating the feeding value of Litsea cubeba pomace as poultry fodder. Luo et al. [133] also explored the utilization value of Litsea cubeba pomace in ruminant feed compared to Leymus chinensis as the control. The rich nutritional value of Litsea cubeba pomace was found to be a kind of feed resource. Nonetheless, the inhibitory effect on the growth of rumen microorganisms was found after Litsea cubeba pomace digestion, which is unfavorable to rumen fermentation and gas production in ruminants.

In addition, roots and barks in Litsea cubeba residual also contain active ingredients such as lignans and alkaloids. A natural dibenzylbutane lignin called 9'-O-di-(E)-feruloylmeso-5, $5^{\prime}$-dimethoxy-secoisolariciresinol (FCL) was found to have anti-inflammatory activity in LPS-induced RAW264.7 cells through the NF- $\mathrm{kB}$ signal pathway [134]. Its antirheumatoid arthritis and anti-osteoporosis properties were also evaluated by measuring cell proliferation, alkaline phosphatase activity, and calcium deposition formation on osteoblasts [135]. The results revealed that FCL promoted osteoblastgenesis and bone formation, while osteoclastogenesis was suppressed. Importantly, FCL showed strong binding activities to the cathepsin $\mathrm{K}$ and mitogen-activated proteinkinase kinase 1 (MEK1), which indicated that FCL may possess anti-osteoporosis potentials targeting cathepsin $\mathrm{K}$ and MEK1. Zhang et al. [136] separated five novel isoquinoline alkaloids and one known compound from Litsea cubeba and evaluated their in vitro antibacterial, antifungal, and cytotoxic properties, where three alkaloids showed antimicrobial activity against the Staphylococcus aureus, Alternaria alternata, and Colletotrichum nicotianae, while two of them exhibited more potent cytotoxicity against all six tumor cell lines tested.

\section{Conclusions \& Perspectives}

In summary, Litsea cubeba, as a new woody plant resource, could be comprehensively utilized toward a zero-waste biorefinery with both economic, social, and ecological benefits. Besides its essential oils being the main product ( $>4000$ tons in China) with various biological activities, its residues ( $>200,000$ tons in China) including kernel, protein, and pomace also showed great potential to be further develop as value-added products in different fields. Unlike other woody plant oils used mainly for food, the generic term "Litsea cubeba oil" can be used as a food flavoring or be a natural synthon for perfume 
industry, or even as the feedstock for biofuel productions. The total valorization of Litsea cubeba set a successful example for other interesting woody plant resources in China, which may inspire a sustainable biorefinery way for alleviating poverty in underdeveloped or developing countries of origin.

Regarding the current "take-make-dispose" linear economic model, developing a circular economy based on the principles of designing out waste and pollution, keeping products and materials in use, and regenerating natural systems seems to be the only solution to the resource-security problem worldwide. For future development of woody oil industry, recirculation of waste materials should be promoted as a priority through adopting well-targeted policies, legislation, financial, and technical measures. For this, life cycle assessment for products from each woody oil plant resource have to be further made to provide decision makers and the market with quantitative environmental performance information in different phases of the product life cycle, resulting in a scientific foundation from a "cradle to grave" perspective for the sustainable development of Litsea cubeba or other plant resources in the same situation.

Author Contributions: Conceptualization, Y.L.; validation, P.L., Y.W. and Y.L.; formal analysis, Y.Q. and Y.L.; investigation, Y.Q., Y.Y. and Y.L.; resources, Y.L. and Y.W.; data curation, Y.Q., Y.Y. and Y.L.; writing — original draft preparation, Y.Q. and Y.Y.; writing — review and editing, Y.L.; visualization, P.L. and Y.L.; supervision, Y.L.; project administration, Y.L. and Y.W.; funding acquisition, Y.L. and Y.W. All authors have read and agreed to the published version of the manuscript.

Funding: This research was funded by the Program for Guangdong YangFan Introducing Innovative and Entrepreneurial Teams, grant number 2016YT03H132 and National Natural Science Foundation of China, grant number 32072252.

Conflicts of Interest: There are no conflict of interest to declare.

\section{References}

1. Dai, Y.; Sun, D.; Yang, X. Research on the status and development proposals for the wood oil industry in China. Cereals Oils 2015, $28,17-19$.

2. Gatto, A.D.; Mengarelli, C.; Pedretti, E.F.; Duca, D.; Pieri, S.; Mangoni, L.; Signor, M.; Raccuia, S.A.; Melilli, M.G. Adaptability of sunflower (Helianthus annuus L.) high oleic hybrids to different Italian areas for biodiesel production. Ind. Crop. Prod. 2015, 75, 108-117. [CrossRef]

3. Lauri, P.; Havlík, P.; Kindermann, G.; Forsell, N.; Böttcher, H.; Obersteiner, M. Woody biomass energy potential in 2050. Energy Policy 2014, 66, 19-31. [CrossRef]

4. Yin, D.; Li, S.; Wu, Q.; Feng, C.; Li, B.; Wang, Q.; Wang, L.; Xu, W. Advances in research of six woody oil crops in China. Chin. Bull. Bot. 2018, 53, 110-125.

5. Yuan, J.; Wang, C.; Chen, H.; Zhou, H.; Ye, J. Prediction of fatty acid composition in Camellia oleifera oil by near infrared transmittance spectroscopy (NITS). Food Chem. 2013, 138, 1657-1662. [CrossRef]

6. Xiao, H.; Yao, Z.; Peng, Q.; Ni, F.; Sun, Y.; Zhang, C.X.; Zhong, Z.X. Extraction of squalene from camellia oil by silver ion complexation. Sep. Purif. Technol. 2016, 169, 196-201. [CrossRef]

7. Gao, P.; Liu, R.J.; Jin, Q.Z.; Wang, X.G. Comparison of solvents for extraction of walnut oils: Lipid yield, lipid compositions, minor-component content, and antioxidant capacity. LWT 2019, 110, 346-352. [CrossRef]

8. Reíter, R.J.; Manchester, L.C.; Tan, D.X. Melatonin in walnuts: Influence on levels of melatonin and total antioxidant capacity of blood. Nutrition 2005, 21, 920-924. [CrossRef]

9. Han, J.G.; Liu, Z.; Li, X.Q.; Li, J.; Hu, Y.H. Diversity in seed oil content and fatty acid composition in three tree peony species with potential as sources of omega-3 fatty acids. Hortic. Sci. Biotechnol. 2016, 91, 175-179. [CrossRef]

10. Li, S.S.; Yuan, R.Y.; Chen, L.G.; Wang, L.S.; Hao, X.H.; Wang, L.J.; Zheng, X.C.; Du, H. Systematic qualitative and quantitative assessment of fatty acids in the seeds of 60 tree peony (Paeonia section Moutan DC.) cultivars by GC-MS. Food Chem. 2015, 173, 133-140. [CrossRef]

11. Wu, S.H.; Wu, D.G.; Chen, Y.W. Chemical constituents and bioactivities of plants from the genus Paeonia. Chem. Biodivers. 2010, 7 , 90-104. [CrossRef]

12. Zhang, S.; Zu, Y.G.; Fu, Y.J.; Luo, M.; Liu, W.; Li, J.; Efferth, T. Supercritical carbon dioxide extraction of seed oil from yellow horn (Xanthoceras sorbifolia Bunge.) and its anti-oxidant activity. Bioresour. Technol. 2010, 101, 2537-2544. [CrossRef]

13. Venegas-Calerón, M.; Ruíz-Méndez, M.V.; Martínez-Force, E.; Garcés, R.; Salas, J.J. Characterization of Xanthoceras sorbifolium Bunge seeds: Lipids, proteins and saponins content. Ind. Crop. Prod. 2017, 109, 192-198. [CrossRef]

14. Liang, Q.; Wang, W.W.; Yuan, F.L.; Liu, X.; Li, D.L.; Yang, K.Q. Characterization of yuanbaofeng (Acer truncatum Bunge) samaras: Oil, fatty acid, and phytosterol content. Ind. Crop. Prod. 2019, 135, 344-351. [CrossRef] 
15. Gu, R.H.; Morcol, T.; Liu, B.; Shi, M.J.; Kennelly, E.J.; Long, C.L. GC-MS, UPLC-QTOF-MS, and bioactivity characterization of Acer truncatum seeds. Ind. Crop. Prod. 2019, 138, 111480. [CrossRef]

16. Zhang, Z.S.; Liu, Y.L.; Che, L.M. Characterization of a new $\alpha$-Linolenic acid-Rich oil: Eucommia ulmoides seed oil. Food Sci. 2018, 83, 617-623. [CrossRef]

17. Xing, Y.F.; He, D.; Wang, Y.; Zeng, W.; Zhang, C.; Lu, Y.; Su, N.; Kong, Y.H.; Xing, X.H. Chemical constituents, biological functions and pharmacological effects for comprehensive utilization of Eucommia ulmoides Oliver. Food Sci. Hum. Wellness 2019, 8, 177-188. [CrossRef]

18. Xiao, Z.H.; Li, C.Z.; Chen, J.Z.; Liu, R.K.; Wu, X.F. Analysis of oil composition in different parts of Cornus wilsoniana Wanger. fruit. China Oils Fats 2009, 34, 72-74.

19. Wang, L.B.; Yu, H.Y.; He, X.H.; Liu, R.Y. Influence of fatty acid composition of woody biodiesel plants on the fuel properties. J. Fuel Chem. Technol. 2012, 40, 397-404. [CrossRef]

20. Zhang, T.; Zhou, W.C.; Xu, H.N.; Jiang, X.M. Industrial refining and physicochemical characteristics of fruit oil from Swida wilsoniana. Food Sci. 2012, 33, 163-166.

21. Qiu, L.Y.; Chen, H.P.; Yan, Y.F.; Li, Y.Y.; Wang, H.; Liao, Z.P.; Huang, Q.R. Sasanquasaponin promotes cellular chloride efflux and elicits cardioprotection via the PKC $\varepsilon$ pathway. Mol. Med. Rep. 2016, 13, 3597-3603. [CrossRef] [PubMed]

22. Yeh, W.J.; Ko, J.; Huang, W.C.; Cheng, W.Y.; Yang, H.Y. Crude extract of Camellia oleifera pomace ameliorates the progression of non-alcoholic fatty liver disease via decreasing fat accumulation, insulin resistance and inflammation. Br. J. Nutr. 2020, 123, 508-515. [CrossRef] [PubMed]

23. Bumrungpert, A.; Pavadhgul, P.; Kalpravidh, R.W. Camellia oil-enriched diet attenuates oxidative stress and inflammatory markers in hypercholesterolemic subjects. J. Med. Food 2016, 19, 895-898. [CrossRef] [PubMed]

24. Lee, C.P.; Yen, G.C. Antioxidant activity and bioactive compounds of tea seed (Camellia oleifera Abel.) oil. J. Agric. Food Chem. 2006, 54, 779-784. [CrossRef] [PubMed]

25. Jung, E.; Lee, J.; Baek, J.; Jung, K.; Lee, J.; Huh, S.; Kim, S.; Koh, J.; Park, D. Effect of Camellia japonica oil on human type I procollagen production and skin barrier function. J. Ethnopharmacol. 2007, 112, 127-131. [CrossRef]

26. Shao, P.; Liu, Q.; Fang, Z.X.; Sun, P.L. Chemical composition, thermal stability and antioxidant properties of tea seed oils obtained by different extraction methods: Supercritical fluid extraction yields the best oil quality. Eur. J. Lipid Sci. Technol. 2015, 117, 355-365. [CrossRef]

27. Mei, L.; Qiao, H.; Ke, F.; Peng, C.; Hou, R.; Wan, X.; Cai, H. One-step synthesis of zirconium dioxide-biochar derived from Camellia oleifera seed shell with enhanced removal capacity for fluoride from water. Appl. Surf. Sci. 2020, 509, 144685. [CrossRef]

28. Cofrades, S.; Serrano, A.; Ayo, J.; Carballo, J.; Jiménez-Colmenero, F. Characteristics of meat batters with added native and preheated defatted walnut. Food Chem. 2008, 107, 1506-1514. [CrossRef]

29. Kong, X.; Zhang, L.; Song, W.; Zhang, C.; Hua, Y.; Chen, Y.; Li, X. Separation, identification and molecular binding mechanism of dipeptidyl peptidase IV inhibitory peptides derived from walnut (Juglans regia L.) protein. Food Chem. 2021, 347,129062 [CrossRef]

30. Zabihi, M.; Haghighi Asl, A.; Ahmadpour, A. Studies on adsorption of mercury from aqueous solution on activated carbons prepared from walnut shell. J. Hazard. Mater. 2010, 174, 251-256. [CrossRef]

31. Wang, G.; Zhang, Y.; Zhang, R.; Pan, J.; Qi, D.; Wang, J.; Yang, X. The protective effects of walnut green husk polysaccharide on liver injury, vascular endothelial dysfunction and disorder of gut microbiota in high fructose-induced mice. Int. J. Biol. Macromol. 2020, 162, 92-106. [CrossRef]

32. Soto-Maldonado, C.; Vergara-Castro, M.; Jara-Quezada, J.; Caballero-Valdés, E.; Müller-Pavez, A.; Zúñiga-Hansen, M.E.; Altamirano, C. Polyphenolic extracts of walnut (Juglans regia) green husk containing juglone inhibit the growth of HL-60 cells and induce apoptosis. Electron. J. Biotechnol. 2019, 39, 1-7. [CrossRef]

33. Rajaram, S. Health benefits of plant-derived $\alpha$-linolenic acid. Am. J. Clin. Nutr. 2014, 100, 443-448. [CrossRef]

34. Lowry, J.R.; Marshall, N.; Wenzel, T.J.; Murray, T.E.; Klegeris, A. The dietary fatty acids $\alpha$-linolenic acid (ALA) and linoleic acid (LA) selectively inhibit microglial nitric oxide production. Mol. Cell. Neurosci. 2020, 109, 103569. [CrossRef]

35. Kim, K.B.; Nam, Y.A.; Kim, H.S.; Hayes, A.W.; Lee, B.M. $\alpha$-Linolenic acid: Nutraceutical, pharmacological and toxicological evaluation. Food Chem. Toxicol. 2014, 70, 163-178. [CrossRef]

36. Yu, H.; Fan, S.; Bi, Q.; Wang, S.; Hu, X.; Chen, M.; Wang, L. Seed morphology, oil content and fatty acid composition variability assessment in yellow horn (Xanthoceras sorbifolium Bunge) germplasm for optimum biodiesel production. Ind. Crop. Prod. 2017, 97, 425-430. [CrossRef]

37. Yao, Z.Y.; Qi, J.H.; Yin, L.M. Biodiesel production from Xanthoceras sorbifolia in China: Opportunities and challenges. Renew. Sustain. Energy Rev. 2013, 24, 57-65. [CrossRef]

38. Fan, H.; Sun, L.; Yang, L.; Zhou, J.; Yin, P.; Li, K.; Xue, Q.; Li, X.; Liu, Y. Assessment of the bioactive phenolic composition of Acer truncatum seed coat as a byproduct of seed oil. Ind. Crop. Prod. 2018, 118, 11-19. [CrossRef]

39. Wang, X.Y.; Fan, J.S.; Wang, S.Y.; Sun, R.C. A new resource of nervonic acid from purpleblow maple (Acer truncatum) seed oil. For. Prod. J. 2006, 56, 147-150.

40. Chen, C.H.; Shen, Y.K.; Hsieh, S.C. The investigation of gutta-percha temperature and compaction force change when using the vertical compaction of warm gutta-percha technique. J. Polym. Eng. 2014, 34, 219-223. [CrossRef] 
41. Dong, M.; Zhang, T.; Zhang, J.; Hou, G.; Yu, M.; Liu, L. Mechanism analysis of Eucommia ulmoides gum reducing the rolling resistance and the application study in green tires. Polym. Test. 2020, 87, 106539. [CrossRef]

42. Zhang, H.; Ma, C.; Sun, R.; Liao, X.; Wu, J.; Xie, M. Sustainable elastomer of triazolinedione-modified Eucommia ulmoides gum with enhanced elasticity and shape memory capability. Polymer 2019, 185, 121904. [CrossRef]

43. Li, N.; Xu, J.; Xu, T. Preparation, properties and modification mechanism of vulcanized Eucommia ulmoides gum modified asphalt Constr. Build. Mater. 2021, 274, 121992. [CrossRef]

44. Chen, W.; Wu, F.W.; Zhang, J.H. Potential production of non-food biofuels in China. Renew. Energy 2016, 85, 939-944. [CrossRef]

45. Fu, J.; Zhang, X.; Liu, K.; Li, Q.; Zhang, L.; Yang, X.; Zhang, Z.; Li, C.; Luo, Y.; He, Z.; et al. Hypolipidemic activity in SpragueDawley rats and constituents of a novel natural vegetable oil from Cornus Wilsoniana fruits. Food Sci. 2012, 77, 160-169. [CrossRef] [PubMed]

46. Huang, C.L.; Wu, S.X.; Hao, Z.J.; Xiao, Z.H. Study on the functional effect of the oils from Swida wilsoniana seeds. Sci. Technol. Food Ind. 2011, 32, 403-405.

47. Zhang, A.H.; Tang, J.; Lie, J.L.; He, Y.D.; Xiao, Z.H. Study on the preparation of biohydrocarbon fuel by catalytic hydrogenation of Swida wilsoniana pyrolysis products. Adv. Mater. Sci. Eng. 2020, 2020, 3569125. [CrossRef]

48. Ding, R.; Zhong, S.A.; Li, N.; Yang, J.J. Transesterification of Swida wilsoniana oil with methanol to biodiesel catalyzed by Lipozyme TL IM in $\mathrm{MgCl}_{2}$-saturated solution. J. Fuel Chem. Technol. 2010, 38, 287-291. [CrossRef]

49. Saikiaa, A.K.; Chetiaa, D.; D'Arrigob, M.; Smerigliob, A.; Stranoc, T.; Ruberto, G. Screening of fruit and leaf essential oils of Litsea cubeba Pers. from north-east India-chemical composition and antimicrobial activity. J. Essent. Oil Res. 2013, 25, 330-338. [CrossRef]

50. Li, Y.; Fabiano-Tixier, A.S.; Vian, M.A.; Chemat, F. Solvent-free microwave extraction of bioactive compounds provides a tool for green analytical chemistry. TrAC Trends Anal. Chem. 2013, 47, 1-11. [CrossRef]

51. Chemat, F.; Rombaut, N.; Sicaire, A.G.; Meullemiestre, A.; Fabiano-Tixier, A.S.; Vian, M.A. Ultrasound assisted extraction of food and natural products. Mechanisms, techniques, combinations, protocols and applications. A review. Ultrason. Sonochem. 2017, 34, 540-560. [CrossRef]

52. Puri, M.; Sharma, D.; Barrow, C.J. Enzyme-assisted extraction of bioactives from plants. Trends Biotechnol. 2012, 30, 37-44. [CrossRef]

53. Da Silva, R.P.; Rocha-Santos, T.A.; Duarte, A.C. Supercritical fluid extraction of bioactive compounds. TrAC Trends Anal. Chem. 2016, 76, 40-51. [CrossRef]

54. Chen, F.; Liu, S.; Zhao, Z.; Gao, W.; Ma, Y.; Wang, X.; Yan, S.; Luo, D. Ultrasound pre-treatment combined with microwave-assisted hydrodistillation of essential oils from Perilla frutescens (L.) Britt. leaves and its chemical composition and biological activity. Ind. Crop. Prod. 2020, 143, 111908. [CrossRef]

55. Liu, X.G.; Chen, M.M.; Chen, X.H.; Xie, B.P. Study on Extracting Citral from Litsea cubeba fruits by microwave radiation and determination of citral. Chem. Ind. For. Prod. 2001, 21, 87-90.

56. Yang, G.; Wang, G.; Li, X.; Zhang, M. Study on new extraction technology and chemical composition of Litsea Cubeba essential oil. Open Mater. Sci. J. 2011, 5, 93-99. [CrossRef]

57. Du, H.; Zhu, H.; Chen, A. Study on Extracting Litsea cubeba oil by ultrasonic-assisted vacuum distillation. Shandong Agric. Sci. 2018, 50, 133-138.

58. Peng, B.; Wang, W.Q.; Liu, H.J.; Zhang, N. Optimizing process of extraction of Litsea cubeba oil and citral. Appl. Chem. Ind. 2013, $42,1786-1788$.

59. Xie, Y.F.; Liang, Y.L.; Wang, F.X.; Xiong, W.J.; Xu, Y.; Liu, X.Y. Study on enzymatic extraction of Litsea cubeba Pers oil. Food Res. Dev. 2013, 34, 57-59.

60. Zhang, D.Q.; Lu, F.J.; Tai, J.X. Study on extracting Litsea cubeba oil with supercritical $\mathrm{CO}_{2}$ fluid technique. Food Ferment. Ind. 2000, $26,54-57$.

61. Guo, Y.; Li, Y.; Li, Z.; Jiang, L.; Cao, X.; Gao, W.; Wang, J.; Luo, D.; Chen, F. Deep eutectic solvent-homogenate based microwaveassisted hydrodistillation of essential oil from Litsea cubeba (Lour.) Pers. Fruits and its chemical composition and biological activity. J. Chromatogr. A 2021, 1646, 462089.

62. Zarena, A.S.; Sachindra, N.M.; Sankar, K.U. Optimisation of ethanol modified supercritical carbon dioxide on the extract yield and antioxidant activity from Garcinia mangostana L. Food Chem. 2012, 130, 203-208. [CrossRef]

63. Zougagh, M.; Valcárcel, M.; Rıs, A. Supercritical fluid extraction: A critical review of its analytical usefulness. TrAC Trends Anal. Chem. 2004, 23, 399-405. [CrossRef]

64. Möse, J.R.; Möse, G. Onkolyseversuche mit apathogenen, anaeroben sporenbildnern am Ehrlich-Tumor der Maus. Arzneim 1959, 63, 63-74.

65. Dai, J.; Li, C.; Cui, H.; Lin, L. Unraveling the anti-bacterial mechanism of Litsea cubeba essential oil against E. coli O157:H7 and its application in vegetable juices. Int. J. Food Microbiol. 2021, 338, 108989. [CrossRef]

66. Hu, W.; Li, C.; Dai, J.; Cui, H.; Lin, L. Antibacterial activity and mechanism of Litsea cubeba essential oil against methicillin-resistant Staphylococcus aureus (MRSA). Ind. Crop. Prod. 2019, 130, 34-41. [CrossRef]

67. Gogoi, R.; Loying, R.; Sarma, N.; Munda, S.; Pandey, S.K.; Lal, M. A comparative study on antioxidant, anti-inflammatory, genotoxicity, anti-microbial activities and chemical composition of fruit and leaf essential oils of Litsea cubeba Pers. from North-east India. Ind. Crop. Prod. 2018, 125, 131-139. [CrossRef] 
68. Yu, A.; Wang, W.; Hu, H.; Wang, L.; Su, J. Synergistic antibacterial and antioxidant effects of Litsea cubeba essential oil and D-borneol. Food Sci. Technol. 2019, 44, 286-291.

69. Wang, H.; Liu, Y. Chemical composition and antibacterial activity of essential oils from different parts of Litsea cubeba. Chem. Biodivers. 2010, 7, 229-235. [CrossRef]

70. Meng, Y.; Cui, H.; Zhao, Q.; Li, M.; Bian, C.; Bai, R.; Ma, Y. Antimicrobial effects and mechanism of action of essential oils against dominant spoilage bacteria isolated from large yellow croaker (Larimichthys crocea) during chilled storage. J. Fish. China 2018, 42, 1140-1153.

71. Niu, B.; Jin, C.; Liang, J.; Shang, R.; Hao, B.; Wang, X.; Yang, Z.; Liu, Y. Chemical constituents and antibacterial activities in vitro of three plant essential oils. Prog. Vet. Med. 2019, 40, 18-23.

72. Liu, T.T.; Yang, T.S. Antimicrobial impact of the components of essential oil of Litsea cubeba from Taiwan and antimicrobial activity of the oil in food systems. Int. J. Food Microbiol. 2012, 156, 68-75. [CrossRef]

73. Gogoi, P.; Baruah, P.; Nath, S.C. Antifungal activity of the essential oil of Litsea cubeba Pers. J. Essent. Oil Res. 1997, 9, 213-215. [CrossRef]

74. Li, Y.; Kong, W.; Li, M.; Liu, H.; Zhao, X.; Yang, S.; Yang, M. Litsea cubeba essential oil as the potential natural fumigant: Inhibition of Aspergillus flavus and $\mathrm{AFB}_{1}$ production in licorice. Ind. Crop. Prod. 2016, 80, 186-193. [CrossRef]

75. Wang, X.; Liang, X.; Gao, M.; Wu, L.; Wang, Y.; Chen, Y. Analysis of chemical constituents and antimicrobial activity of essential oils in three species from May Chang tree. Nat. Prod. Res. Dev. 2019, 31, 1847-1856.

76. He, H.; Zhu, Y.; Wang, Z.; Liu, P.; Zhan, M.; Zeng, X. Inhibitory effects of ten plant essential oils on three pathogens of cherry tomatoes. Sci. Technol. Food Ind. 2016, 37, 153-157.

77. Huang, Y.; Li, H.; Xu, X.; Li, Y.; Dong, T. In vitro susceptibility study of Litsea cubeba oil and its combination with ketoconazole, itraconazole and fluconazole against Malassezia. J. Clin. Dermatol. 2016, 45, 565-568.

78. You, L.; Lin, N.; Guo, H.; Liao, X.; Wei, Q. On Diversity of endophytic fungi isolated from Litsea Cubeba. J. Southwest China Norm. Univ. 2013, 38, 121-126.

79. Ju, J.; Xie, Y.; Yu, H.; Guo, Y.; Cheng, Y.; Zhang, R.; Yao, W. Major components in Lilac and Litsea cubeba essential oils kill Penicillium roqueforti through mitochondrial apoptosis pathway. Ind. Crop. Prod. 2020, 149, 112349. [CrossRef]

80. Thielmann, J.; Theobald, M.; Wutz, A.; Krolo, T.; Buergy, A.; Niederhofer, J.; Welle, F.; Muranyi, P. Litsea cubeba fruit essential oil and its major constituent citral as volatile agents in an antimicrobial packaging material. Food Microbiol. 2021, 96, 103725. [CrossRef]

81. Hwang, J.K.; Choi, E.M.; Lee, J.H. Antioxidant activity of Litsea cubeba. Fitoterapia 2005, 76, 684-686. [CrossRef]

82. She, Q.H.; Li, W.S.; Jiang, Y.Y.; Wu, Y.C.; Zhou, Y.H.; Zhang, L. Chemical composition, antimicrobial activity and antioxidant activity of Litsea cubeba essential oils in different months. Nat. Prod. Res. 2020, 34, 3285-3288. [CrossRef]

83. Wang, Y.; Cen, C.; Chen, J.; Zhou, C.; Fu, L. Nano-emulsification improves physical properties and bioactivities of Litsea cubeba essential oil. LWT 2021, 137, 110361. [CrossRef]

84. Chen, F.; Peng, Y.; Yan, X.; Lin, H.; Zeng, D.; Zhang, Y. Chemical components and bioactivity of essential oil derived from Litsea cubeba against Aedes albopictus. Chin. J. Biol. Control 2012, 28, 521-527.

85. Seo, S.M.; Kim, J.; Lee, S.G.; Shin, C.H.; Shin, S.C.; Park, I.K. Fumigant antitermitic activity of plant essential oils and components from ajowan (Trachyspermum ammi), allspice (Pimenta dioica), caraway (Carum carvi), dill (Anethum graveolens), geranium (Pelargonium graveolens), and litsea (Litsea cubeba) oils against Japanese termite (Reticulitermes speratus Kolbe). J. Agric. Food Chem. 2009, 57, 6596-6602.

86. Noosidum, A.; Prabaripai, A.; Chareonviriyaphap, T.; Chandrapatya, A. Excito-repellency properties of essential oils from Melaleuca leucadendron L., Litsea cubeba (Lour.) Persoon, and Litsea salicifolia (Nees) on Aedes aegypti (L.) mosquitoes. J. Vector Ecol. 2008, 33, 305-312. [CrossRef]

87. Wu, H.; Zhang, M.; Yang, Z. Repellent activity screening of 12 essential oils against Aedes albopictus Skuse: Repellent liquid preparation of Mentha arvensis and Litsea cubeba oils and bioassay on hand skin. Ind. Crop. Prod. 2019, 128, 464-470. [CrossRef]

88. Yang, K.; Wang, C.F.; You, C.X.; Geng, Z.F.; Sun, R.Q.; Guo, S.S.; Du, S.S.; Liu, Z.L.; Deng, Z.W. Bioactivity of essential oil of Litsea cubeba from China and its main compounds against two stored product insects. J. Asia Pac. Entomol. 2014, 17, 459-466. [CrossRef]

89. Park, I.K.; Kim, J.; Lee, S.G.; Shin, S.C. Nematicidal Activity of Plant Essential Oils and Components from ajowan (Trachyspermum ammi), allspice (Pimenta dioica) and litsea (Litsea cubeba) essential oils against pine wood nematode (Bursaphelenchus Xylophilus). J. Nematol. 2007, 39, 275-279.

90. Luo, Q.; Wang, Z.; Wang, X.; Lu, Y. Fumigation activity of five plant oils against adults of Liposcelis Entomophila (Enderlein). J. Henan Univ. Technol. Nat. Sci. Ed. 2016, 37, 82-86.

91. Zhang, H.J.; Zheng, L.H.; Zhao, K.; Gao, H.R.; Luo, S.; Chen, Y.; Wang, T. Separation and identification of insecticidal constituents of Litsea cubeba. Sci. Technol. Cereals Oils Foods 2016, 24, 65-68.

92. Jiang, Z.; Akhtar, Y.; Bradbury, R.; Zhang, X.; Isman, M.B. Comparative toxicity of essential oils of Litsea pungens and Litsea cubeba and blends of their major constituents against the cabbage looper, Trichoplusia ni. J. Agric. Food Chem. 2009, 57, $4833-4837$. [CrossRef] [PubMed]

93. Pumnuan, J.; Chandrapatya, A.; Insung, A. Acaricidal activities of plant essential oils from three plants on the mushroom mite, Luciaphorus perniciosus Rack (Acari: Pygmephoridae). Pak. J. Zool. 2010, 42, 247-252. 
94. Amer, A.; Mehlhorn, H. Repellency effect of forty-one essential oils against Aedes, Anopheles, and Culex mosquitoes. Parasitol. Res. 2006, 99, 478-490. [CrossRef]

95. Chen, H.C.; Chang, W.T.; Hseu, Y.C.; Chen, H.Y.; Chuang, H.C.; Lin, C.C.; Lee, M.S.; Lin, M.K. Immunosuppressive Effect of Litsea cubeba L. Essential Oil on Dendritic Cell and Contact Hypersensitivity Responses. Int. J. Mol. Sci. 2016, 17, 1319. [CrossRef] [PubMed]

96. Yin, Z.; Wang, Q.; Ja, Y. Empirical study on antiasthmatic effect of citral from aqueous extract of fruit of Litsea cubeba tree. Chin. J. Clin. Pharmacol. Ther. 2006, 11, 197-201.

97. Tang, J.; Wan, J.; Shi, C.; Fang, J.; Wang, W. Technology of supercritical $\mathrm{CO}_{2}$ extraction from Fructus Litseae and its analgesic activity. Cent. South Pharm. 2008, 6, 301-303.

98. Ho, C.L.; Ou, J.P.; Liu, Y.C.; Hung, C.P.; Tsai, M.C.; Liao, P.C.; Wang, E.I.C.; Chen, Y.L.; Su, Y.C. Compositions and in vitro anticancer activities of the leaf and fruit oils of Litsea cubeba from Taiwan. Nat. Prod. Commun. 2010, 5, 617-620. [CrossRef]

99. Choi, E.M.; Hwang, J.K. Effects of methanolic extract and fractions from Litsea cubeba bark on the production of inflammatory mediators in RAW264.7 cells. Fitoterapia 2004, 75, 141-148. [CrossRef]

100. Zhong, Y.M.; Zheng, Q.M.; Wang, L.; Zeng, X.L.; Cao, L.Q. Study on the anti-inflammatory, anti-cancer activities and fresh-keeping effect of Litsea cubeba oil. Guangdong Agric. Sci. 2014, 41, 100-105.

101. Huang, X.W. Chemical Composition and Tyrosinase Inhibition Activity and Antioxidant Activities of Three Essential Oils. Master's Thesis, Huazhong University of Science and Technology, Hubei, China, 2013.

102. Chen, C.J.; Tseng, Y.H.; Chu, F.H.; Wen, T.Y.; Cheng, W.W.; Chen, Y.T.; Tsao, N.W.; Wang, S.Y. Neuropharmacological activities of fruit essential oil from Litsea cubeba Persoon. J. Wood Sci. 2012, 58, 538-543. [CrossRef]

103. Chaiyasut, C.; Sivamaruthi, B.S.; Wongwan, J.; Thiwan, K.; Rungseevijitprapa, W.; Klunklin, A.; Kunaviktikul, W. Effects of Litsea cubeba (Lour.) Persoon essential oil aromatherapy on mood states and salivary cortisol levels in healthy volunteers. Evid. Based Complement. Altern. Med. 2020, 2020, 4389239. [CrossRef]

104. Gnatta, J.R.; Kurebayashi, L.F.S.; Turrini, R.N.T.; Silva, M.J.P. Aromatherapy and nursing: Historical and theoretical conception. Rev. Esc. Enferm. USP 2016, 50, 127-133. [CrossRef]

105. Liu, X.; Chen, M.; Xie, B. Extraction of citral from Litsea Cubeba fruits and determination of citral. Fine Chem. 2001, 18, 398-400.

106. Peng, X.L.; Cai, B.L.; Fu, H.J. Study on separation and purification of citral in Litsea Cubeba essential oil. China For. Prod. Ind. 2018, $45,17-22$.

107. Fu, H.J.; Peng, X.L.; Kuang, C.T.; Zong, H.Y. Separation of citral from Litsea cubeba oil by phase transfer catalysis. Food Mach. 2016, 9, 161-165.

108. Zhong, C.Y.; Zhou, Z.M.; Huang, H.Y.; Li, Y.J. Process improvement of refining citral from Litsea cubeba oil. Guangxi For. Sci. 2013, $42,387-389$.

109. Cheng, J.; Shi, B.J.; Jiang, H.F.; Zhu, Y.Y.; Zhang, W.M. Study on purifying high quality citral from Litsea cubeba oil. Sci. Technol. Food Ind. 2015, 36, 231-234.

110. Huang, M.; Zhong, Z.S. Process for purification of Litsea cubeba oil by molecular distillation. Food Sci. Technol. $2005,8,52-54$.

111. Hu, T.; Wang, Y.; Pi, S.F.; Sun, H.Z.; Li, J.L. Process conditions of synthesis ionone from citral. Food Mach. $2014,30,224-227$.

112. Xing, K.; You, K.; Yin, D.; Yuan, Z.; Mao, L. A simple and efficient approach for synthesis of pseudoionone from citral and acetone catalyzed by powder $\mathrm{LiOH} \cdot \mathrm{H}_{2} \mathrm{O}$. Catal. Commun. 2009, 11, 236-239. [CrossRef]

113. Huang, Z.L.; Lu, H.F.; Wei, G.F.; Huang, H.; Wei, L.B. Synthesis of lemonile from citral under microwave assisted solvent-free condition with phase transfer catalysis of polyethylene glycol 600. Fine Chem. 2008, 25, 576-579.

114. Liu, X.G.; Chen, M.M.; Xiong, Y.F.; Huang, X.G. Synthesis of irone. Flavour Fragr. Cosmet. 2001, 2, 5-7.

115. Nik Norulaini, N.A.; Setianto, W.B.; Zaidul, I.S.M.; Nawi, A.H.; Azizi, C.Y.M.; MohdOmar, A.K. Effects of supercritical carbon dioxide extraction parameters on virgin coconut oil yield and medium-chain triglyceride content. Food Chem. 2009, 116, 193-197. [CrossRef]

116. Liu, R.; Tang, S.; Xiao, Z.; Zhang, A.; Li, P.; Sun, F.; Li, H.; Li, C.; Xia, L. The impact of processing techniques on composition of Litsea cubeba kernel oil. Hunan For. Sci. Technol. 2017, 44, 68-71.

117. Li, X.; Zhou, J.; Ren, T.; Yang, G. Extraction technology and chemical composition of Litsea cubeba kernel oil. J. For. Eng. 2016, 1, 54-58.

118. He, Y.; Xiao, Z.; Du, G.; Zhang, A. The extraction of Litsea cubeba oil by microwave-assisted water extraction method. Hunan For. Sci. Technol. 2018, 45, 51-56.

119. Zhu, H.; Sun, J.; Peng, L.; Lai, C.; Zhu, C. Optimization of microwave-assisted extraction of Litsea cubeba kernel oil by response surface methodology. Guihaia 2017, 37, 1074-1082.

120. Chen, T.B.; Yuan, X.Y.; Zhang, M. Study on Extraction Technology of Litsea cubeba Kernel Oil by Supercritical Carbon Dioxide. Biomass Chem. Eng. 2009, 43, 5-8.

121. Zhuang, X.; Zhang, Z.; Wang, Y.; Li, Y. The effect of alternative solvents to n-hexane on the green extraction of Litsea cubeba kernel oils as new oil sources. Ind. Crop. Prod. 2018, 126, 340-346. [CrossRef]

122. Zhou, J.; Ren, T.; Li, X.; Yang, G. Preparation of high purity lauric acid from Litsea cubeba kernel oil. China Oils Fats 2016, 41, 64-67.

123. Zhou, J.; Li, X.; Yang, G.; Qian, W.; Li, R. The extraction, purification of Litsea Cubeba kernel oil and its application in the synthesis of surfactant. China For. Prod. Ind. 2013, 40, 13-16. 
124. Yuan, L.; Yuan, X.Y.; Jia, G.; Yao, K.; Hu, T. Study on acetal types degradable surfactants synthesized by Litsea Cubeba kernel oil. J. Hunan Univ. Sci. Eng. 2012, 33, 49-52.

125. Chemat, F.; Vian, M.A.; Ravi, H.K. Toward petroleum-free with plant-based chemistry. Curr. Opin. Green Sustain. Chem. 2021, 28, 100450. [CrossRef]

126. Wang, F.; Chang, Z.; Duan, P.; Yan, W.; Xu, Y.; Zhang, L.; Miao, J.; Fan, Y. Hydrothermal liquefaction of Litsea cubeba seed to produce bio-oils. Bioresour. Technol. 2013, 149, 509-515. [CrossRef]

127. Zhang, Q.; Zhou, K.; Ma, P. Preparation of biodiesel from Litsea cubeba kernel oil. Chem. Eng. Oil Gas 2015, $44,14-17$.

128. Li, D.; Feng, W.; Chen, C.; Chen, S.; Fan, G.; Liao, S.; Wu, G.; Wang, Z. Transesterification of Litsea cubeba kernel oil to biodiesel over zinc supported on zirconia heterogeneous catalysts. Renew. Energy 2021, 177, 13-22. [CrossRef]

129. Schneider, M.P. Plant-oil-based lubricants and hydraulic fluids. J. Sci. Food Agric. 2006, 86, 1769-1780. [CrossRef]

130. Cai, Z.; Zhuang, X.; Yang, X.; Huang, F.; Wang, Y.; Li, Y. Litsea cubeba kernel oil as a promising new medium-chain saturated fatty acid feedstock for biolubricant base oil synthesis. Ind. Crop. Prod. 2021, 167, 113564. [CrossRef]

131. Zhang, Y.; Qiu, C.; Wang, Y.; He, J.; Zhang, Z. Optimization of protein alkali extraction technology from Litsea cubeba and its functional properties. China Oils Fats 2019, 44, 52-57.

132. Zhang, X.; Yao, Y.; Li, C.; Huang, X.; Jang, G.; Zhou, W.; Dai, Q. Study on Nutrient and Energy Utilization Rate of Rooster and Duck on Litsea Cubeba Residue. Chin. J. Anim. Sci. 2020, 56, 131-134.

133. Luo, Y.; Li, H.; He, F.; Huan, C.; Li, J.; Yi, K.; Sun, A. Effects of Litsea cubeba Residue on Rumen Fermentation Characteristics of Hu Sheep in Vitro. J. Henan Agric. Sci. 2020, 49, 142-147.

134. Lin, B.; Sun, L.N.; Xin, H.L.; Nian, H.; Song, H.T.; Jiang, Y.P.; Wei, Z.Q.; Qin, L.P.; Han, T. Anti-inflammatory constituents from the root of Litsea cubeba in LPS-induced RAW 264.7 macrophages. Pharm. Biol. 2016, 54, 1741-1747. [CrossRef] [PubMed]

135. Peng, W.; Shen, H.; Lin, B.; Han, P.; Li, C.H.; Zhang, Q.Y.; Ye, B.Z.; Rahman, K.; Xin, H.L.; Qin, L.P.; et al. Docking study and ntiosteoporosis effects of a dibenzylbutane lignan isolated from Litsea cubeba targeting Cathepsin K and MEK1. Med. Chem. Res. 2018, 27, 2062-2070. [CrossRef]

136. Zhang, W.; Hu, J.F.; Lv, W.W.; Zhao, Q.C.; Shi, G.B. Antibacterial, antifungal and cytotoxic isoquinoline alkaloids from Litsea cubeba. Molecules 2012, 17, 12950-12960. [CrossRef] 